\title{
Single-Cell Analysis of Circulating Tumor Cells: Why Heterogeneity Matters
}

\author{
Su Bin $\operatorname{Lim}{ }^{1,2} \mathbb{D}$, Chwee Teck $\operatorname{Lim} 1,2,3,4$ (D) and Wan-Teck Lim $5,6,7, *$ \\ 1 NUS Graduate School for Integrative Sciences \& Engineering, National University of Singapore, \\ Singapore 117456, Singapore; sblim@u.nus.edu (S.B.L.); ctlim@nus.edu.sg (C.T.L.) \\ 2 Department of Biomedical Engineering, National University of Singapore, Singapore 117583, Singapore \\ 3 Mechanobiology Institute, National University of Singapore, Singapore 117411, Singapore \\ 4 Institute for Health Innovation and Technology (iHealthtech), National University of Singapore, \\ Singapore 117599, Singapore \\ 5 Division of Medical Oncology, National Cancer Centre Singapore, Singapore 169610, Singapore \\ 6 Office of Academic and Clinical Development, Duke-NUS Medical School, Singapore 169857, Singapore \\ 7 IMCB NCC MPI Singapore Oncogenome Laboratory, Institute of Molecular and Cell Biology (IMCB), \\ Agency for Science, Technology and Research (A*STAR), Singapore 138673, Singapore \\ * Correspondence: darren.lim.w.t@singhealth.com.sg; Tel.: +65-6436-8000
}

Received: 30 September 2019; Accepted: 16 October 2019; Published: 19 October 2019

\begin{abstract}
Unlike bulk-cell analysis, single-cell approaches have the advantage of assessing cellular heterogeneity that governs key aspects of tumor biology. Yet, their applications to circulating tumor cells (CTCs) are relatively limited, due mainly to the technical challenges resulting from extreme rarity of CTCs. Nevertheless, recent advances in microfluidics and immunoaffinity enrichment technologies along with sequencing platforms have fueled studies aiming to enrich, isolate, and sequence whole genomes of CTCs with high fidelity across various malignancies. Here, we review recent single-cell CTC (scCTC) sequencing efforts, and the integrated workflows, that have successfully characterized patient-derived CTCs. We examine how these studies uncover DNA alterations occurring at multiple molecular levels ranging from point mutations to chromosomal rearrangements from a single CTC, and discuss their cellular heterogeneity and clinical consequences. Finally, we highlight emerging strategies to address key challenges currently limiting the translation of these findings to clinical practice.
\end{abstract}

Keywords: single-cell analysis; cellular heterogeneity; circulating tumor cells

\section{Introduction}

The concept of intratumoral heterogeneity (ITH), first described in 1982 by Fidler and Hart [1], has been expanded to include genetic, phenotypic and functional heterogeneity within tumors comprising diverse malignant and non-malignant subpopulations. With accumulations of mutations in DNA damage checkpoint control genes and DNA repair genes, divergent cancer clones may evolve and propagate over time through selection processes driven by constantly changing microenvironment and by the use of therapy $[2,3]$. In addition to genetic heterogeneity in clonal mutations and subclonal de novo mutations, functional heterogeneity related to developmental pathways and epigenetic programs and spatial variability in tumor microenvironment contribute to ITH, which governs key aspects of tumor biology, including tumor invasion, metastasis, and drug resistance [2].

Recent years have also seen the contribution of non-malignant cells, such as stromal fibroblasts, immune cells, bone-marrow-derived cells, mesenchymal stem cells, and endothelial cells, to ITH within a tumor. Malignant and benign cells interact locally through a complex network of extracellular matrix 
$(\mathrm{ECM})$ and the related components, collectively termed as matrisome, which has been linked to tumor progression, response to adjuvant therapy, and immune system [4-7], driving tumor phenotypes supporting their metastatic competence. The tumor cells can be shed passively (through corrupted blood vessel) and/or actively (through epithelial-mesenchymal transition (EMT)) from tumors into the circulation, referred to as circulating tumor cells (CTCs), in which only a minority of cell populations survive under the physiological blood flow and succeed in early colonization phases [8]. Despite the low frequency of occurrence, CTCs allow for repeated sampling, which is not clinically practical for tissue biopsy, and may thus be an excellent tool for assessing tumor heterogeneity and for revealing clonal diversity underlying resistance to treatment [9].

The prevalence of phenotypic plasticity involving programmed death-ligand 1 (PD-L1) [10], stemness [11], drug resistance [12], and EMT [13], within CTC populations has fueled investigation of cellular heterogeneity using single-cell high-throughput enrichment and sequencing platforms over the past five years. Emerging single-cell RNA sequencing (scRNA-seq) data further suggest that CTCs may interact with hematopoietic cells or platelets in blood through direct and/or indirect routes, adding another layer of heterogeneity [14]. Bulk-cell approaches traditionally deployed in existing CTC literature, however, have provided insights into cellular processes averaged throughout the enriched blood sample, which largely comprises leukocytes, or white blood cells (WBCs). The leukocyte contamination is inevitable in any given primarily enriched sample due in part to extremely rare CTCs occurring at a frequency of $\sim 1$ in $10^{7} \mathrm{WBC}$ in blood from a cancer patient [15] and the relatively low cell capture efficiency of existing cell sorting technologies, which are further limited to isolating only certain CTC subpopulations (refer to the Section 2.1 for further details). It is therefore essential to reach single-cell resolution to precisely characterize CTCs at the genomic level and further to investigate the clinical impact of cellular heterogeneity present within CTC populations.

\section{Methods and Technologies}

Despite technical challenges, single-cell CTC (scCTC) analyses have so far revealed genomic variations specific to each CTC, including mutations that are not yet present in the Catalogue of Somatic Mutations in Cancer (COSMIC) database [16-20] or subclonal alterations that are not easily discernible from tissue biopsies [16,17], cells of origin of cancer (e.g., bone marrow-derived multiple myeloma) [21], or with bulk-cell approaches [22], providing comprehensive landscape of evolving tumor cells. Such private genomic variations shared by CTCs may represent "CTC phenotypes", including intravasation competency, increased migration/motility, enhanced cell-cell interactions, variation in energy metabolism, interaction with platelet and blood immune cells, resistance to anoikis, and resistance to therapy $[19,23]$. Single nucleotide variations (SNVs) and/or copy number variations $(\mathrm{CNVs})$ in these putative precursors of metastasis present early in clonal evolution or in tumor progression may be excellent targets for therapeutic intervention. Examined below are scCTC DNA sequencing studies that have successfully assessed DNA alterations in patient-derived CTCs across various cancer types (Table 1). 
Table 1. Summary of single-cell circulating tumor cells (scCTC) sequencing studies that analyzed DNA alterations in patient-derived CTCs.

\begin{tabular}{|c|c|c|c|c|c|c|c|c|}
\hline CTC Enrichment & Single-Cell Isolation & СТС Criteria & WGA & Profiling & Investigated Genes & Genomic Analysis & $\begin{array}{c}\text { Number of Single CTCs } \\
\text { (Patients) }^{1}\end{array}$ & Ref. \\
\hline \multicolumn{9}{|c|}{ Prostate cancer } \\
\hline MagSweeper & CellCelector & DAPI- CD45- EpCAM+ & MDA & NGS & All & SNVs & $42(5)$ & [24] \\
\hline Epic Sciences CTC Platform & Micromanipulation & $\mathrm{CD} 45-\mathrm{CK}+1-$ & DOP-PCR & NGS & All & CNVs, LSTs & $\begin{array}{l}67(7) \\
67\end{array}$ & [25] \\
\hline NanoVelcro CTC Chip & LCM & CD45-CK+ & MDA & NGS, Sanger, aCGH & All & SNVs, SVs, CNVs & $12(1)$ & [26] \\
\hline HD-CTC Assay & Micromanipulation & DAPI+ CK+ CD45- & LA-PCR & NGS & All & CNVs & 41 (1) & [27] \\
\hline $\begin{array}{l}\text { CellSearch, Spectra Optia } \\
\text { Apheresis System }\end{array}$ & FACS & DAPI + CK + CD45- & LA-PCR & aCGH & All & CNVs & $205(14)$ & [17] \\
\hline \multicolumn{9}{|c|}{ Breast cancer } \\
\hline MagSweeper & Micromanipulation & DAPI+ CK+ CD45- & No WGA & Sanger & PIK3CA & SNVs & $185(11)$ & [28] \\
\hline CellSearch & $\begin{array}{l}\text { DEPArray } \\
\text { DEOT }\end{array}$ & DAPI+ CK+ CD45- & LA-PCR & $\begin{array}{l}\text { Sanger } \\
\text { Sanger }\end{array}$ & $\begin{array}{l}\text { TP53 } \\
\text { TP5 }\end{array}$ & SNVs & $11(2)$ & [29] \\
\hline & & & & Sanger & PIK3CA & SNVs & $241(43)$ & \\
\hline CellSearch & DEPArray & DAPI+ CK+ CD45- & LA-PCR & $\mathrm{gPCR}$ & HER2 & CNVs & $192(42)$ & [30] \\
\hline & & & & aCGH & All & CNVs & 37 (15) & \\
\hline Cellsearch & DEPArray & DAPI+ CK+ CD45- CD34- & LA-PCR & Sanger & РІКЗСА & SNVs & $115(18)$ & [18] \\
\hline CellSearch & DEPArray & DAPI+ CK+ CD45- & LA-PCR & Targeted NGS & $\begin{array}{l}50 \text { cancer-related } \\
\text { genes }\end{array}$ & SNVs & $14(4)$ & [31] \\
\hline Leukapheresis, CellSearch & Micromanipulation & $\mathrm{CK}+\mathrm{CD} 45-$ & DOP-PCR & CGH & $\begin{array}{c}\text { genes } \\
\text { All }\end{array}$ & CNVs & $65(19)$ & [32] \\
\hline Cellsearch & MoFlo XDP flow-sorting & DAPI + CK+ CD45- & LA-PCR & $\begin{array}{l}\text { aCGH } \\
\text { qPCR } \\
\text { Sanger }\end{array}$ & $\begin{array}{c}\text { All } \\
\text { CCND1 locus } \\
\text { PIK3CA, TP53 }\end{array}$ & $\begin{array}{l}\text { CNVs } \\
\text { CNVs } \\
\text { SNVs }\end{array}$ & $26(12)$ & [33] \\
\hline FACS & DEPArray & $\begin{array}{l}\text { DAPI- CD45- EpCAM- } \\
\text { CD44+ CD24- uPAR+/- } \\
\text { int } \beta 1+/-\end{array}$ & LA-PCR & MassARRAY & $\begin{array}{l}>200 \text { hallmark } \\
\text { cancer genes }\end{array}$ & SNVs & $7(-)$ & [34] \\
\hline CellSearch & Micromanipulation & DAPI+ CK+ CD45- & MDA, LA-PCR & Sanger & PIK3CA & SNVs & $114(33)$ & [35] \\
\hline CellSearch & DEPArray & DAPI + CK + CD45- & LA-PCR & $\begin{array}{l}\text { Targeted NGS, } \\
\text { ddPCR }\end{array}$ & 50 COSMIC genes & SNVs & $40(5)$ & [36] \\
\hline CellSearch & CellCelector & DAPI+ CK+ CD45- & LA-PCR & Targeted NGS & 50 COSMIC genes & SNVs & $7(2)$ & [37] \\
\hline CellSearch & DEPArray & $\mathrm{DAPI}+\mathrm{CK}+\mathrm{CD} 45-$ & LA-PCR & Sanger & $\begin{array}{l}\text { TP53, HER2, } \\
\text { PIK3CA, RB1 }\end{array}$ & SNVs & $24(6)$ & [38] \\
\hline Ficoll Separation & Micromanipulation & DAPI + CK + CD45- & LA-PCR & Sanger & $\begin{array}{l}\text { PIKLA, KB1 } \\
\text { ESR1 }\end{array}$ & SNVs & $8(4)$ & [39] \\
\hline AutoMACS Classic Separator & LCM & CK+ CD $45-$ & LA-PCR & SNP Array & All & CNVs & $17(17)$ & [23] \\
\hline CellSearch, Oncoguick & CellCelector & EpCAM+ CD45- & MDA & aCGH, targeted NGS & All & SNVs, CNVs & $31(1)$ & {$[40]$} \\
\hline oHSV-hTERT-GFP method & FACS & CD45-hTERT+ & MALBAC & NGS & All & SNVs, CNVs & 11 (8) & [19] \\
\hline ScreenCell & DEPArray & DAPI+ CK+ CD45- & LA-PCR & Sanger & TP53, ESR1 & SNVs & 7 (1) & {$[41]$} \\
\hline ClearCell FX System & Manipulation & DAPI+ CK+ CD45- & MALBAC & NGS & All & SNVs & $3(1)$ & [20] \\
\hline
\end{tabular}


Table 1. Cont.

\begin{tabular}{|c|c|c|c|c|c|c|c|c|}
\hline CTC Enrichment & Single-Cell Isolation & СTC Criteria & WGA & Profiling & Investigated Genes & Genomic Analysis & $\begin{array}{c}\text { Number of Single CTCs } \\
\text { (Patients) }^{1}\end{array}$ & Ref. \\
\hline \multicolumn{9}{|c|}{ Lung cancer } \\
\hline CellSearch & DEPArray & DAPI+ CK+ CD45- & LA-PCR & NGS & All & CNVs & $72(13)$ & [42] \\
\hline Cellsearch & Micromanipulation & DAPI+ CK+ CD45- & MALBAC & $\begin{array}{l}\text { NGS, digital PCR, } \\
\text { Sanger }\end{array}$ & All & $\begin{array}{l}\text { SNVs, INDELs } \\
\text { CNVs }\end{array}$ & $\begin{array}{l}24(4) \\
61(11)\end{array}$ & [43] \\
\hline ClearCell FX System & Microfluidic chip & DAPI+ CK+ CD45- & No WGA & Sanger & EGFR & SNVs & $26(7)$ & [44] \\
\hline CellSearch & Micromanipulation & DAPI+ CK+ CD45- & MALBAC & NGS & All & $\begin{array}{l}\text { SNVs, INDELs, } \\
\text { CNVs, SVs }\end{array}$ & $97(23)$ & [45] \\
\hline Cellsearch & Micromanipulation & DAPI+ CK+ CD45- & MALBAC & NGS & All & $\begin{array}{l}\text { SNVs, INDELs, } \\
\text { CNVs, SVs }\end{array}$ & $91(10)$ & [46] \\
\hline MagSifter & Single-Nanowell Assay & $\begin{array}{c}\text { DAPI+ CK+ CD } 45-\text { TERT }+ \\
\text { MET+ } \\
\end{array}$ & No WGA & Multiplex PCR & EGFR & SNVs & $202(7)$ & [22] \\
\hline \multicolumn{9}{|c|}{ Colorectal cancer } \\
\hline \multirow{3}{*}{ CellSearch } & \multirow{3}{*}{ Micromanipulation } & \multirow{3}{*}{ EpCAM+ CD45- CK+ } & \multirow{3}{*}{ LA-PCR } & aCGH & All & CNVs & $8(8)$ & \\
\hline & & & & Sanger & KRAS, BRAF, TP53 & SNVs & $126(31)$ & [47] \\
\hline & & & & Multiplex PCR & $\begin{array}{l}\text { NCI/ICG-HNPCC } \\
\text { marker panel }\end{array}$ & MSI & $122(30)$ & \\
\hline \multirow[t]{2}{*}{ CellSearch } & \multirow[t]{2}{*}{ Micromanipulation } & \multirow[t]{2}{*}{ DAPI+ CK+ CD45- } & \multirow[t]{2}{*}{ LA-PCR, MDA } & aCGH & $\begin{array}{c}\text { All } \\
68 \text { colorectal }\end{array}$ & CNVs & $37(6)$ & [16] \\
\hline & & & & Targeted NGS & $\begin{array}{l}\text { cancer-associated } \\
\text { genes }\end{array}$ & SNVs & $8(2)$ & \\
\hline CellSearch & Micromanipulation & DAPI+ CK+ CD45- & LA-PCR, MDA & $\begin{array}{c}\text { qPCR } \\
\text { Sanger }\end{array}$ & $\begin{array}{l}\text { EGFR } \\
\text { KRAS, BRAF, } \\
\text { PIK3CA }\end{array}$ & $\begin{array}{l}\text { CNVs } \\
\text { SNVs }\end{array}$ & $\begin{array}{l}26(3) \\
69(5)\end{array}$ & [48] \\
\hline Oncoquick & DEPArray & HOECHST + CK+ CD45- & LA-PCR & $\begin{array}{c}\text { Sanger, } \\
\text { pyrosequencing }\end{array}$ & KRAS & SNVs & $-(16)$ & [49] \\
\hline \multicolumn{9}{|c|}{ Melanoma } \\
\hline Dynabeads & LCM & $\begin{array}{l}\text { HMW-MAA+ CD45- } \\
\text { MART-1/gp100+ }\end{array}$ & No WGA & Sanger & $\begin{array}{l}\text { BRAF } \\
\text { KIT }\end{array}$ & $\begin{array}{l}\text { SNVs } \\
\text { SNVs }\end{array}$ & $\begin{array}{l}14(9) \\
4(4)\end{array}$ & [50] \\
\hline $\begin{array}{l}\text { Dielectrophoretic microwell } \\
\text { array }\end{array}$ & Micromanipulation & CD45- MART-1/gp100+ & No WGA & Sanger & BRAF & SNVs & $33(1)$ & [51] \\
\hline \multicolumn{9}{|c|}{ Multiple myeloma } \\
\hline MACS beads & Micromanipulation & CD45-CD138+ & MDA & Targeted NGS & $\begin{array}{l}35 \text { most commonly } \\
\text { mutated loci }\end{array}$ & SNVs & $203(10)$ & [21] \\
\hline Epic Sciences CTC Platform & Micromanipulation & $\mathrm{CK}+/-\mathrm{CD} 45-$ & DOP-PCR & NGS & All & CNVs & $9(1)$ & [52] \\
\hline \multicolumn{9}{|c|}{ Pancreatic cancer } \\
\hline NanoVelcro Chip & LCM & $\begin{array}{l}\text { HOECHST+ CD45- } \\
\text { CK/CEA+ }\end{array}$ & MDA & Sanger & KRAS & SNVs & $60(12)$ & [53] \\
\hline
\end{tabular}

${ }^{1}$ QC-passed CTCs that have been included in the final analysis. 


\subsection{CTC Enrichment}

Once collected, blood samples are subjected to CTC enrichment using density gradient centrifugation, 2D/3D microfiltration, microfluidic devices, or immunoaffinity-based technologies (Figure 1; refer to Ref. [14] for detailed summary and comparison of existing CTC enrichment technologies). While CellSearch ${ }^{\circledR}$ remains the choice of primary enrichment tool in scCTC sequencing studies, such immunoaffinity-based enrichment technology relying on epithelial cell surface markers (e.g., EpCAM or CKs) have varying capture efficiency depending on the degree of EMT, stemness, and the resulting differentiation cell state. $\mathrm{EpCAM}^{+} \mathrm{CK}^{+}$cells have also been detected by CellSearch ${ }^{\circledR}$ in patients with benign diseases, but in lower frequency compared to the cancer group [54]. Clinical data supporting the metastatic competence of $\mathrm{EpCAM}^{-} \mathrm{CTC}$ in numerous studies $[34,55]$ have further fueled the transition in the field to the development of label-free approaches leveraging on biophysical properties of CTCs (e.g., size, density, stiffness).

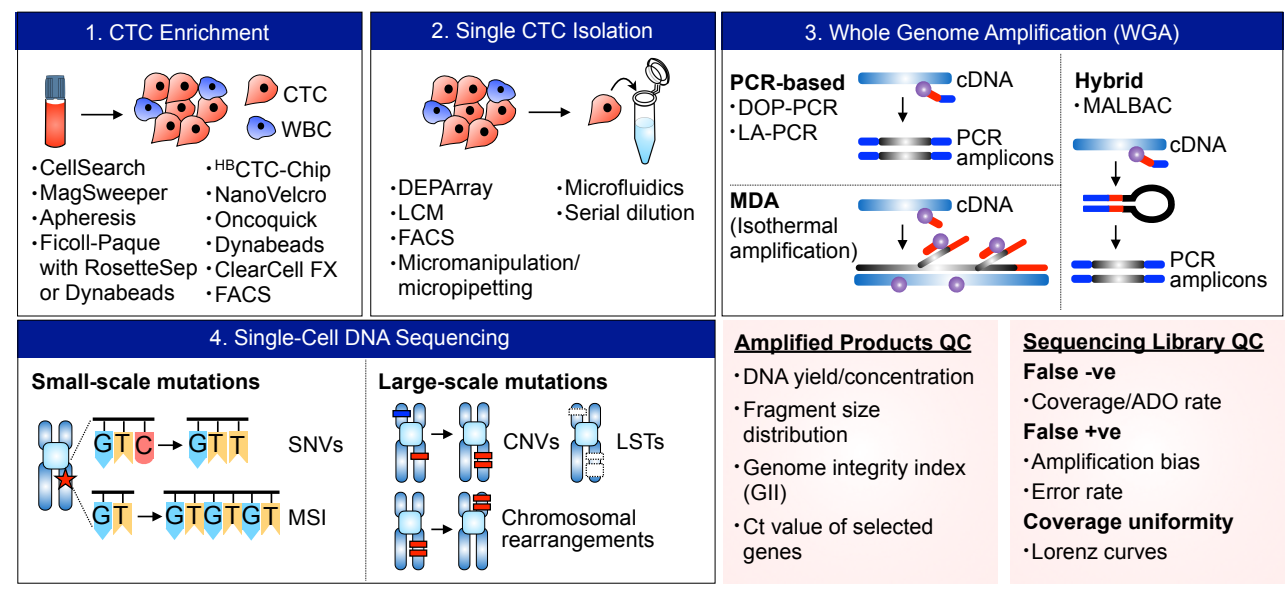

Figure 1. The standard workflow and existing technologies for scCTC sequencing. CTCs are primarily enriched from a whole blood sample, and are isolated as single cells for subsequent downstream molecular analyses. For genomic analysis of whole genome/exome, whole-genome amplification (WGA) is performed and amplified DNA products are QC-checked prior to sequencing.

One of our pioneering efforts in developing such marker-independent technology was the application of inertial microfluidics using spiral microchannels, in which depth and width of each channel can be designed to control the positioning of cells or microparticles in suspension via Dean flow fractionation (DFF). Our technology, so-called ClearCell ${ }^{\circledR}$ FX, enriches intact and viable CTCs from the peripheral blood of cancer patients in a fully automated and high-throughput fashion, with a reported $>80 \%$ sensitivity and specificity in detecting CTCs from clinical samples (refer to [56] for further details on the system). Mechanobiologically inspired enrichment platforms achieve high sensitivity and are not limited to certain CTC subpopulations, yet the purity of enriched samples may be compromised due to their size distribution overlapping with leukocytes, as observed in breast, colorectal, and prostate cancer [57]. To best interrogate CTCs and their cellular heterogeneity, cell enrichment technology should thus be carefully selected for unbiased capture and recovery of different CTC subpopulations.

\subsection{Single-Cell Isolation}

CTC enrichment technologies are used in conjunction with microscopic micromanipulators (e.g., Eppendorf Transfer Man NK2/4 micromanipulator, CellCelector $\left.{ }^{\mathrm{TM}}\right)$, laser capture microdissection (LCM) [26], microfluidic devices [44], or DEPArray ${ }^{\mathrm{TM}}$ to recover putative CTCs as single cells. Enriched cells are often fixed and stained with the nucleic acid dye DAPI and monoclonal antibodies specific to epithelial cell surface marker cytokeratin (CK) and leukocyte marker CD45, and manually selected by the trained and skilled operator based on DAPI and CK positivity and CD45 negativity. Morphology 
of the captured cells (e.g., cell shape, size) are concurrently assessed to identify cells having 4 to $40 \mu \mathrm{m}$ diameter, round or oval shape, and/or high nuclear/cytoplasm ratio [37,39,49].

Even though dozens of CTCs might have been captured in CTC enrichment step, only very few single CTCs $(<10$ CTCs) have been isolated and transferred successfully to a PCR tube per sample $[4,19,49]$. Such low recovery rate could be attributed to apoptotic CTCs, which are often excluded from the isolation in most scCTC sequencing studies. Consistent with the classic definition of apoptosis, these cells are defined as $\mathrm{CK}^{+} \mathrm{CD} 45^{-}$CTCs with non-intact nuclei having DAPI pattern of chromosomal condensation and/or nuclear fragmentation and blebbing [52]. Given that low burden of apoptotic CTCs has been associated with poor prognosis and aggressive phenotypes across several cancer types [52,58], characterization of CTC apoptosis in situ may facilitate the development of new platform for real-time monitoring of antitumor drug efficacy.

\subsection{Whole-Genome Amplification (WGA)}

WGA is an active area of development with wide applications to study rare tumor cells or single-celled organisms, such as bacteria and archaea. There exist different WGA approaches based on specific, degenerate, and/or hybrid primers: Linker-adapter PCR (LA-PCR), interspersed repetitive sequence PCR (IRS-PCR), primer extension preamplification (PEP-PCR), degenerate oligonucleotide primed PCR (DOP-PCR), displacement degenerate oligonucleotide primed PCR (D-DOP-PCR), multiple displacement amplification (MDA), single primer isothermal amplification (SPIA), and multiple annealing and looping-based amplification cycles (MALBAC; refer to ref. [59] for a comprehensive summary on working principles and characteristics of each WGA method).

Briefly, LA-PCR and IRS-PCR methods utilize specific primers, each amplifying digested DNA litigated to adapter fragments and repeating sequence elements, respectively, while the rest of the methods, such as PEP-PCR, DOP-PCR, and D-DOP-PCR, are based on the use of degenerated primers. MDA has been commonly applied to single-cell sequencing of microorganisms as well as patient-derived CTCs. It employs a unique polymerase with strong strand displacement activity (e.g., phi29 DNA polymerase), which can amplify fragments of up to $100 \mathrm{~kb}$ with high replication fidelity compared to purely PCR-based (e.g., Taq polymerase) methods [59]. MALBAC has been proposed as a hybrid PCR/MDA method, relying on two relatively error-prone DNA polymerases, Bst DNA polymerase and Taq DNA polymerase, for isothermal strand displacement and PCR, respectively. Each WGA technique has its own advantages and limitations in terms of sensitivity, specificity, uniformity, and amplification bias. For example, while LA-PCR, DOP-PCR, and MALBAC may be the choice of method for detection of CNVs but not SNVs, MDA (REPLI-g ${ }^{\mathrm{TM}}$ ) has proven to be most sensitive in detecting mutations at a single-base resolution compared to LA-PCR methods (GenomePlex ${ }^{\mathrm{TM}}$, Ampli1 ${ }^{\mathrm{TM}}$ ) [60].

The challenge is that the yield of amplified DNA varies significantly across CTCs, where the success rate of amplification ranges from $11 \%$ to $100 \%$ [24,61], and WGA step itself is subjected to coverage biases and errors, such as preferential allelic amplification, GC bias, dropout events, and nucleotide copy errors [60]. To account for such variability, studies have established an additional QC step prior to in-depth sequencing to probe only CTCs with yields of DNA greater than negative controls [24] or a fixed concentration level [27] or those showing specific bands corresponding to targets of interest on the Agilent 2100 Bioanalyzer $[19,29]$. The author-defined QC assays have also been developed to identify CTCs suited for single-cell targeted sequencing and analysis. For example, genome integrity index (GII), which is determined from detectable PCR bands corresponding to three Mse fragments and KRAS fragment, has been proven to be predictive of successful analysis of sequence-based molecular changes, including point mutations, gene amplifications, and CNVs [30,36,42].

\subsection{Sequencing and Profiling}

Amplified DNA samples are subjected to library preparation and quantification. To date, scCTC studies have most commonly employed next-generation sequencing (NGS), Sanger sequencing, single nucleotide polymorphism (SNP), and array comparative genomic hybridization (aCGH) platforms, 
and conventional PCR technologies to analyze somatic SNVs, structural variations, (SVs), CNVs, and chromosomal breakpoints and rearrangements for whole exome/genome or selected cancer-associated genes, often comparatively with matched primary tumors and/or metastatic tissues or disseminated tumor cells (DTCs).

In the library QC step, the sequencing depth, percentage of area covered, homogeneity of coverage, and/or SNP densities are assessed to only select high-quality CTC libraries based on author-defined assessment techniques, such as autocorrelation analysis [24] and Lorenz curves [26]. Fluorimetric assays (e.g., Fluorometer) and analytical tool provided by the sequencing platform (e.g., Torrent Suite) may also be used to quantify DNA samples and to assess the performance of sequencing runs and the quality of generated data, respectively $[19,31,37]$. In some cases, the variants identified by NGS were specifically selected and further validated by Sanger sequencing $[31,45]$ or digital droplet PCR (ddPCR) [36] using the same samples.

The sequence queried in single CTCs in prior studies vary from small-scale mutations $(<1 \mathrm{~kb})$ to large-scale mutations $(1 \mathrm{~kb}-100 \mathrm{Mb})$. Targeting larger regions may come with the trade-off of increased number of false variant calls and sequencing costs and reduced number of individual cells to be sequenced [62]. Nevertheless, whole-genome sequencing (WGS) allows new discoveries of genomic variations occurring even in non-coding regions that may add significant values to the analysis of rare tumor cells.

\section{CTC Heterogeneity and Clinical Impact}

While resolving cellular heterogeneity, single-cell approaches may link specific CTC subpopulation programs to cancer cell phenotypes, metastasis, patient outcomes, and drug resistance, as demonstrated by recent studies. Examined below are genomic aberrations commonly analyzed in CTCs and their clinical impact (Figure 2). Clinical data derived from scCTC transcriptomic analyses are discussed elsewhere [14].

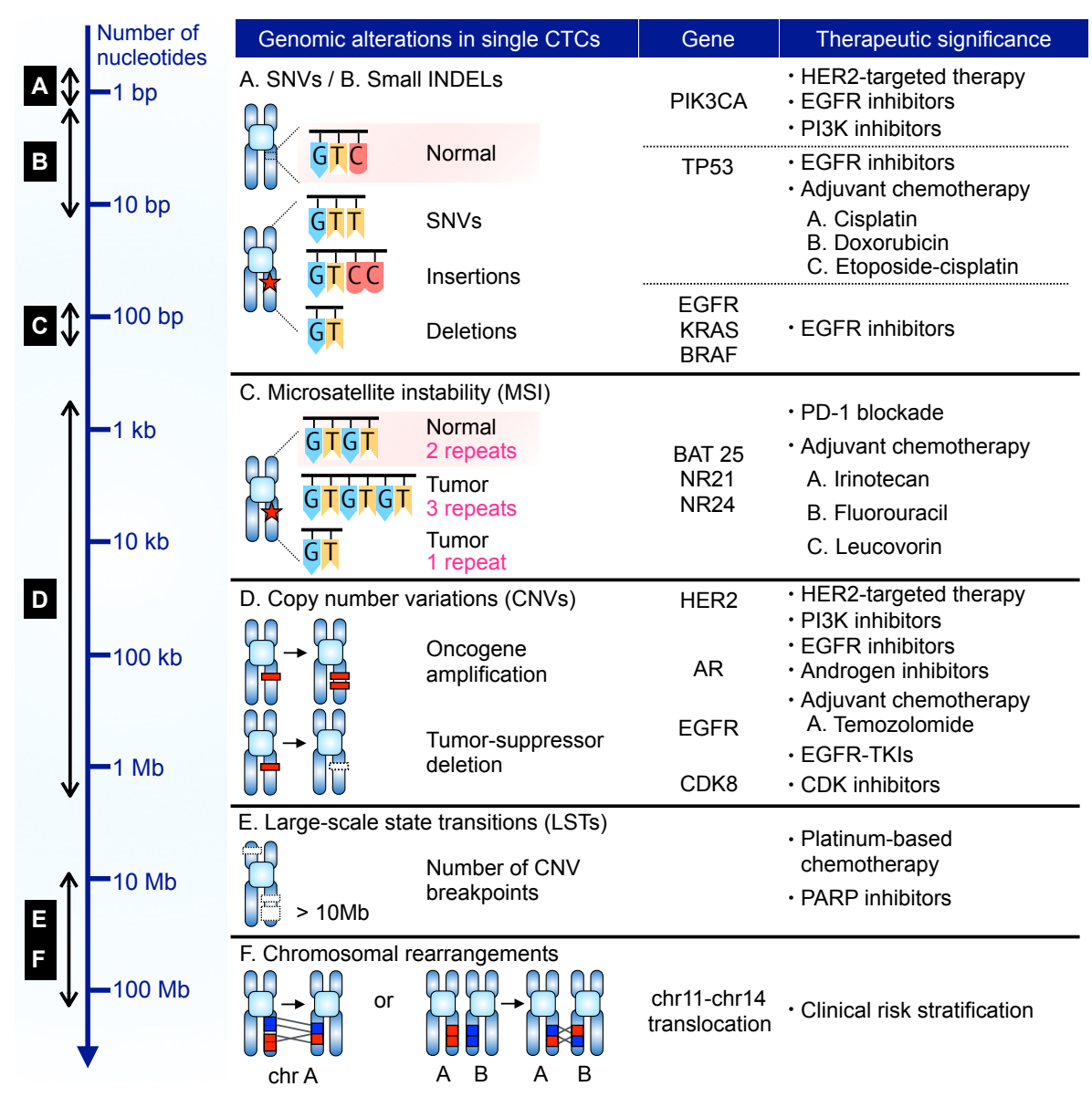

Figure 2. Summary of genomic alterations found in scCTC sequencing studies. 


\subsection{Single Nucelotide Variation (SNV)}

\subsubsection{PIK3CA}

PIK3CA is a gene harboring major driver mutations in many cancer types $[63,64]$. Its mutational status has increasingly been recognized as a promising predictor of resistance to targeted therapies [65]. In breast cancer, tumors harboring PIK3CA mutations are often resistant to HER2-based therapy [66-68], and are less likely to achieve pathologic complete response to anti-HER2 treatments [69,70]. Though limited to the analysis of EpCAM-expressing CTCs, scCTC studies have applied targeted sequencing approaches to examine mutational hotspots, most commonly in exon 9 and 20 [16,18,28,30,35,37,48,71]. The assessment of pre-existing resistant clones through scCTC analysis prior to the administration of HER2-based therapies has been suggested to be of clinical significance for patients harboring CTCs with HER2 amplification and double-mutant PIK3CA/HER2 [30]. Longitudinal monitoring of therapy response through HER2 mutational analysis of CTCs in this subset of patients will be of particular clinical interest, given the known drug efficacy of PIK3CA pathway inhibitors in patients with HER2 ${ }^{+}$ primary tumors [72],

PIK3CA mutational status in CTCs indicative of resistance against HER2-targeted therapy has been demonstrated for HER2 ${ }^{-}$metastatic breast cancer patients screened for German multicentric phase III trial (i.e., DETECT III study) harboring HER2 ${ }^{+}$CTCs [35]. Further, studies have noted a high degree of intrapatient cellular heterogeneity and discordant PIK3CA status between CTCs and matched primary tumors $[18,28,35,36]$, of which PIK3CA was one of two genes (among > 2200 COSMIC mutations analyzed) frequently mutated in CTCs, cfDNA, and matched primary tumor in HER2 ${ }^{-}$ breast cancer [36]. PIK3CA mutation has also been implicated in drug resistance of EGFR tyrosine kinase inhibitor (TKI) treatment. Notably, a lung cancer patient harboring PIK3CA mutation in almost all CTCs (7/8 CTCs) but not in primary tumor (low abundance) had progressive disease and presented distant metastasis after one month of treatment with erlotinib. Early detection of such resistant cells in such a less invasive way may thus be tremendously useful in drug selection.

\subsubsection{TP53}

TP53 is a tumor suppressor gene frequently mutated in most human cancers [73]. TP53 mutations have functional implications in key molecular events in tumor progression, such as EMT [74], stemness [75], cancer prognosis, and survival outcomes [76]. Highly heterogeneous TP53 mutational status was observed across individual CTCs in prostate [24], lung [43], colorectal [16], and breast cancer $[29,31,36,38,41]$. In metastatic prostate cancer, ubiquitous TP53 mutations were found among multiple foci of the primary tumor and metastases, suggesting divergent cancer evolution from a single ancestor cancer [24].

In breast cancer, TP53 harbored the highest number of mutations across CTCs [31]. Mutant TP53 p.R273C has been associated with cisplatin chemotherapy resistance [77]. Concurrent mutations of RB1 and TP53 genes were also found in the majority of CTCs from a lung cancer patient who experienced a phenotypic transition from adenocarcinoma to small-cell lung cancer (SCLC) [43]. Notably, dramatic clinical response was observed in this patient upon etoposide-cisplatin treatment, which is a standard chemotherapy for SCLC patients $[78,79]$. These studies altogether highlight how scCTC profiling may provide an early signal of phenotypic transition in tumor to guide new therapeutic regimen.

\subsubsection{EGFR}

Despite promising efficacy of EGFR in multiple cancer types [80], prediction of response against EGFR inhibition still remains ambiguous. The mere assessment of EGFR expression at the DNA or protein level using bulk primary tumor samples has not been an ideal indicator for predicting the response to anti-EGFR drugs [81,82]. Whole-exome sequencing of lung CTCs revealed specific INDEL in the EGFR gene (p.Lys746_Ala750del) shared by primary tumors and metastases, which could be targeted with TKIs [43]. In our earlier work, we reported highly sensitive detection of EGFR mutations 
(T790M and L868R) in microfluidically enriched CTCs, which showed a complete concordance of mutation status with matched primary tumors in non-small-cell lung cancer (NSCLC) patients [44]. Similarly, an integrated method using a magnetic sifter (MagSifter) and nanowell system has been described for accurate detection of EGFR (del19, T790M, and L868R) mutations in CTCs from lung cancer patients [22]. Notably, RT-qPCR readings of bulk blood samples did not reach detectable level to be analyzed for same mutations in this study [22].

\subsubsection{KRAS}

KRAS, one of the genes involved in the EGFR signaling pathway, may have predictive value of clinical response to anti-EGFR therapies, such as cetuximab [83], panitumumab [84], and gefitinib [85]. Patients exhibited mutational disparity between CTCs and matched primary tumors and/or across individual CTCs in breast [36], colorectal [47-49], and multiple myeloma [24], and breast cancer [36]. This may explain the variable response to anti-EGFR treatment in these cancer patients. Similarly, a highly varying degree of concordance in KRAS mutational status between CTCs and primary/metastatic lesions was observed, reflecting intratumoral heterogeneity of point mutations in KRAS occurring in $48-76 \%$ of various cancers [86].

\subsubsection{BRAF}

Another mutation predictive of response to EGFR-inhibiting therapy is BRAF, which is associated with a very poor prognosis particularly in colorectal cancer and melanoma [87]. Further, the predictive values of V600E and V601E mutations have been demonstrated for the use of RAF kinase inhibitor (vemurafenib) and MEK inhibitor (trametinib), respectively, in BRAF-mutated melanomas [50,88]. Somatic missense mutations in BRAF have been found in approximately $10 \%$ and $60 \%$ of colorectal tumors and melanoma lesions, respectively $[50,89]$. Single-cell genomic characterization of CTCs across these cancer types have revealed highly heterogeneous BRAF status across CTCs [47,48,50,51], with disparities in BRAF mutations to the corresponding primary tumor $[47,50]$. While such considerable heterogeneity observed in these selected genes might be the result of newly acquired mutations in CTCs, it is likely that these mutations were missed by single sector-based tissue biopsies. Through the additional deep sequencing of tissue samples, other groups indeed found mutations that were initially unique to CTCs in the primary tumors and metastases at subclonal level [16].

\subsection{Microsatellite Instability (MSI)}

Defective DNA mismatch repair (MMR) machinery leads to hypermutation and instability in nucleotide repeat sequences [90]. MSI is an established prognostic [91-93] and predictive marker [94,95] in many cancer types. In colorectal cancer (CRC), tumors with high-level MSI, or MSI-H phenotype account for $\sim 15 \%$ of metastatic disease [96], and have distinct pathologic and clinical features [97]. MSI typing may serve as a predictor of benefit from adjuvant 5-fluorouacil chemotherapy for non-MSI-H CRC patients $[95,98]$. The standard MSI assessment recommended by the National Cancer Institute/International Collaborative Group/HNPCC (NCI/ICG-HNPCC) involves the examination of two mononucleotide repeats and three dinucleotide repeats in tumor and non-tumor adjacent normal tissues [99].

A comprehensive genomic study of CRC identified microsatellite stable (MSS) tumor harboring MSI CTCs, through aCGH, mutational profiling, and MSI analyses at the single-cell level [47]. Of note, immunohistochemical (IHC) expression analysis of DNA MMR proteins (i.e., MLH1, MSH2, MSH6, and PMS2) in multiple sectors obtained from matched primary tumor and metastatic lesions did not indicate MSI-H status in this patient. Such discordance was also found in mutational profiles, where mutations in key genes such as KRAS and TP53 were detectable only in CTCs but not in the tumor. Given that contaminating stromal cells or surrounding non-tumor cells in the tissue may obscure MSI, single-cell approaches will be essential for MSI typing. 


\subsection{Copy-Number Variation (CNV)}

With the advent of SNP/aCGH arrays and NGS technologies, identification and characterization of CNVs in primary and metastatic tumors have provided insight into the role of CNVs in cellular functions and cancer pathogenesis [100-102]. Gain of oncogenes and loss of tumor suppressors are frequent drivers of tumor progression, and are closely associated with therapeutic responses [103]. In CTCs, genome-wide CNVs were found to be highly reproducible from cell to cell within the same individual and across different lung cancer patients with same pathological subtypes $[43,45]$. This is consistent with homogeneity found in CTCs from SCLC [42,46] and colorectal cancer patients [45].

While harboring a substantial number of genomic aberrations, CTCs exhibit concordant changes in chromosomes observed in matched primary and/or metastatic tumors, supporting their malignant origin, but to different extents across individual CTC, as demonstrated in colorectal [45,47], breast [40], and bladder [52] cancers. For example, phylogenetic analysis of CNV profiles identified homozygous deletion of a chromosomal region containing the tumor suppressor gene, PTEN, in CTCs and lymph node metastases, but not in primary tumor, suggesting that such CTC subsets might have metastasized in colorectal cancer [45].

A unique signature of recurrent CNVs specific to CTCs was also found in breast cancer, consisting of genes and miRNAs related to CTC phenotypes, such as resistance to anoikis, TGF $\beta$ signaling, and metastasis [23]. This copy number signature clustered patients into two groups, independent of subtype, revealing distinct functional or metastatic features in different populations. Gain of a chromosomal region harboring the HER2 gene was further consistently observed across CTCs regardless of HER2 status of matched primary tumors in this study, suggesting a potential role of HER2 amplification in CTC biology. Notably, HER2 amplification associated with the degree of chromosomal changes was identified in another multi-scale scCTC study, where a significantly higher number of genomic rearrangements was observed in breast CTCs with HER2 amplification than those without amplification, whereas no such change was seen for PIK3CA mutations [30].

CNV profiling of CTCs could potentially be used as a tool for risk stratification. CNV-based classifiers that can assign SCLC patients as chemosensitive or chemorefractory have been developed [42,46], one of which have been validated in an independent patient cohort [42]. The two patient groups stratified by these classifiers were found to have significant different progression-free survival (PFS) and/or overall survival (OS), demonstrating prognostic and predictive value of CTC CNV profiles [42,46]. Further, apheresis-acquired, $\mathrm{CK}^{+}$CTCs harboring $>10$ chromosomal alterations were associated with risk of early metastasis [32]. Better therapeutic strategies may also be inferred from sequential single-cell characterization of CNV changes in CTCs over the course of treatment; MYC amplification occurred along with AR protein expression and AR amplification in a prostate cancer patient progressing through targeted therapy [27]. While direct targeting of MYC proves to be difficult, scCTC data suggest that co-targeting of c-Myc in conjunction with AR may serve as an alternative path to prevent the emergence of drug-resistant subclones.

\subsection{Chromosomal Breakpoints}

In addition to focal $\mathrm{CNV}$ analyses, whole genome-wide $\mathrm{CNV}$ profiles have been extensively analyzed in bulk primary tumors. They are often associated with therapeutic resistance against platinum-based chemotherapy and PARP inhibitors [104]. Large-scale state transition (LST), which is defined as the number of chromosomal breaks between adjacent regions of at least $10 \mathrm{Mb}$, is one of surrogates of such large-scale genomic instability. Significantly higher and heterogeneous LST scores were observed in CTCs from metastatic castration resistant prostate cancer (mCRPC) patients compared to cancer cell lines and WBCs from healthy donors, implying unstable CTC genomes at the single-cell level [25]. The ability to assess genomic instability with LST scoring could potentially improve risk stratification for therapeutic strategies. 


\subsection{Chromosomal Rearrangement}

Two SVs common in all CTCs and both primary and metastatic tumors were found in prostate cancer [26]: TMEM207 in chr3, which facilitates tumor invasion, migration, and metastasis [105,106], and chr13-chr15 translocation. An extensive assessment further revealed heterogeneous status of SVs involving tumor suppressor genes, such as BRCA2, RB1, and PTEN, which are common in prostate cancer [107]. Heterogeneous status of PTEN SVs in single CTCs may suggest the acquirement of variations at different time-points, as PTEN point mutations emerges as a late event during cancer evolution [108]. Parallel transcriptomic profiling for detecting such SVs encoding oncogenes or tumor suppressors that carry founder mutation will further allow discovery of novel fusion products.

\section{Longitudinal Studies}

While it has long been recognized that CTC count could serve as a robust predictor of patient outcomes in breast, prostate, and colorectal cancers [36,39,109-112], CTC enumeration at a single time point alone may not provide sufficient information in terms of treatment regimen. Alternatively, phenotyping of CTCs with morphometric parameters and protein expression has been shown to be better correlated with therapy response $[27,113]$. Another major advantage of CTC profiling is the feasibility to analyze longitudinal samples to study mechanisms related to acquired resistance to therapy (Figure 3). Yet, such analyses may be challenging in the absence of evident de novo global chromosomal changes upon relapse and progression, requiring larger patient cohorts [42].

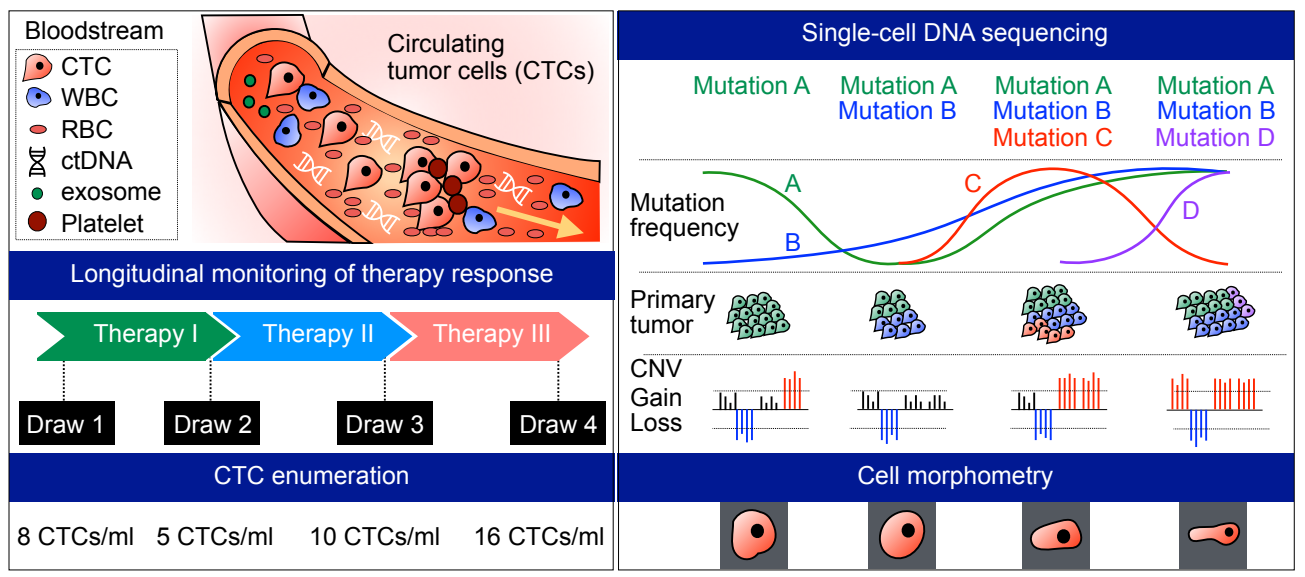

Figure 3. scCTC DNA sequencing for longitudinal monitoring of therapy response.

Selection of patients for targeted therapy has been based on the IHC detection of protein of interest and/or fluorescence in situ hybridization-based analysis of gene-level alterations, typically in known oncogenes, using primary tumor tissues. An underlying assumption is that only marker-positive patients will respond to mutant oncogene-targeted therapy. These treatments may include vemurafenib (BRAF inhibitor) for melanoma patients with V600E/V600K mutation in the BRAF gene [114], Neratinib (HER2 TKI) [115], trastuzumab (HER2 antibody) [116] and pertuzumab (HER2 antibody) [117] for breast cancer patients with amplification and/or overexpression of the HER2 gene, and erlotinib (EGFR TKI) for non-small cell lung cancer patients with exon 19 deletion or L858R mutation in the EGFR gene [118].

Such oncogene-targeted therapies, however, should carefully be applied in the clinical settings. IHC detection of EGFR expression in bulk tumor tissue alone, for example, may not be an ideal tool for prediction of response to gefitinib [119]. Discordance in genomic profiles between primary and recurring/metastatic tumors [120-122] attributed to clonal changes, sampling error in clonal selection, and/or technical flaws in the assay has complicated the decision-making process in treatment selection. Repeat biopsy for marker reassessment does not guarantee improved accuracy, nor is it without false-negative readings [123]. 
Varying genomic status of oncogenes has thus been re-evaluated with CTC pools over the course of therapy. Studies have examined the feasibility of detection of HER2 ${ }^{+}$CTCs in patients with HER2 ${ }^{-}$ primary tumors $[124,125]$ and that of KRAS-mutated CTCs in patients with nonmutated colorectal primary tumor and mutated metastases [89]. Notably, it was found that treatment with trastuzumab, an anti-HER2 antibody traditionally prescribed for patients with HER2 ${ }^{+}$primary tumor, was shown to be effective in improving survival outcomes of patients with HER2 ${ }^{-}$tumor by eliminating $\mathrm{CK}^{+} \mathrm{HER} 2^{+}$ CTCs [126]. This was the first study that clearly demonstrated the potential of CTCs to effectively monitor evolving mutational landscape reflecting time-varying changes in drug susceptibility. Since then, several prospectively conducted studies have been carried out to facilitate the phenotyping and genetic characterization of CTCs as targeted-therapeutic intervention in metastatic cancer [127].

Longitudinal genomic data on SNVs and CNVs have so far been obtained in scCTC studies where CTCs were collected in a sequential manner during the course of treatment in lung $[42,43]$ and prostate cancer [17]. A unique set of somatic CNV variations distinct from those observed in response to standard chemotherapy, was identified in single prostate CTCs at the time of targeted therapy failure, inferring rapidly evolving genomic organization and the emergent putative-resistant clones [27]. In another study where single-cell characterization was done before and during treatment for a breast cancer patient, while CTCs revealed distinct mutational profiles at different time points, all CTCs harbored mutation in the HER2 gene (p.V777L), regardless of sampling time, indicating resistance to HER2-targeted treatment in this patient. Interestingly, the best treatment response to chemotherapy with capecitabine and vinerolbine was observed in a patient who had the highest number of mutated genes and sequence variants in single breast CTCs [31].

Not all longitudinal studies, however, have demonstrated a clear association between CTCs and metastatic status. PIK3CA mutational status in majority of breast CTCs (7 out of 9 blood draws) sequentially sampled over time was not reflective of bone and lung metastases while DTCs achieved $100 \%$ concordance in a patient with progressive metastatic breast cancer [28]. Such highly discordant results, however, may be attributed to EpCAM-based approach employed in this study for CTC enrichment, missing out de-differentiated $\mathrm{EpCAM}^{-}$or mesenchymally shifted CTCs, all of which may be major constituents of putative metastatic founders [4].

\section{Challenges and Emerging Technologies}

Clearly, recent CTC studies have uncovered new perspectives in tumor biology and cancer management, through the application of rare cell sorting and single-cell sequencing technologies. Practically, however, there are challenges and technical errors associated with the developed workflows presented in this work.

\subsection{Fresh-Frozen Versus Formalin-Fixed}

Immunoaffinity-based enrichment technologies, including CellSearch ${ }^{\circledR}$, involve a fixation step, which makes use of fixatives to stabilize whole blood for up to $96 \mathrm{~h}$. Yet, fixed CTCs may be not suitable for RNA-based measurements, ex vivo culture and expansion, drug screening, and xenograft model-based functional studies, for compromised cell viability and degraded RNAs. Alternatively, multiparametric flow cytometry or FACS can be used to keep viable CTCs, which can further be expanded ex vivo to generate patient-derived 3D-spheroids, as demonstrated in prostate and breast cancers $[17,34]$. DEPArray ${ }^{\mathrm{TM}}$ and microfluidic technologies can also be used to isolate viable CTCs for subsequent molecular screening on a cell-per-cell basis.

To preserve cell viability, peripheral blood sample should be delivered on ice immediately to the laboratory once collected from a cancer patient. RNA degradation occurs within $2-4 \mathrm{~h}$, and sample processing $>5 \mathrm{~h}$ after the blood draw may result in $>60 \%$ loss in CTC yield [128]. Similar to tissue acquisition of solid lesions, these requirements impose practical challenges in hospitals and labs, particularly for longitudinal cohort studies. Nevertheless, emerging technologies may be applied to CTCs to circumvent such issues, through the use of nuclear RNA or preservation protocol that 
retains cell viability and RNA quality for up to $72 \mathrm{~h}$ for single-cell transcriptomic profiling. Studies have demonstrated high concordance between nuclear RNA and whole cell RNA in the expression of cell-type specific and metabolic modeling genes [129], and that between fresh and preserved blood in detecting cancer-specific transcripts [128]. Alternatively, frozen-optimized scRNA-seq protocols (e.g., Nuc-seq) may be applied to CTC profiling, which will be particularly useful for serial monitoring of previously inaccessible tissues [2].

\subsection{Increasing Number of CTC Libraries}

Among all the steps, WGA was found to be the most error-prone step in performing scCTC sequencing, with allele dropout (ADO) being a significant source of failure for scCTC sequencing [53]. Such prevalent limitations may be overcome if the amount of DNA template is increased. For example, it has been suggested that at least 10 CTCs are required to reliably detect point mutations in KRAS from pancreatic CTCs [53]. Similarly, sequencing multiple independent libraries of CTCs has been proposed to improve sensitivity in determining variants and to better represent bulk library from a matched primary tumor in prostate cancer [24]. The development of WGA methods providing improved uniformity in genome-wide coverage of the amplified DNA may further facilitate reproducible and accurate sequencing for clinical use.

Alternatively, highly sensitive CTC enrichment technologies may be applied to scCTC sequencing studies to capture, assumedly, all CTCs present in blood so as to generate more DNA templates. Recently, methods of performing single-cell CNV analysis of CTCs acquired by apheresis was described in prostate and breast cancers [17], where CTCs harvested from an apheresis (mean volume $=59.5 \mathrm{~mL}$ ) achieved approximately 90-fold increased yield $($ CTC count $=12,546)$ [17]. Extrapolation analysis further indicated that CTCs might be concentrated along with the mononuclear cell populations during diagnostic leukapheresis (DLA), thereby enhancing CTC detection frequency even in nonmetastatic cancer patients, as compared to standard CTC blood tests processing a volume of 1-10 mL of peripheral blood [32].

In recent years, scRNA-seq technologies coupled with massively parallel microfluidics have enabled high-throughput analysis of mouse retinal cells [130], human macrophages [131], embryonic stem cells [132], and peripheral blood mononuclear cells (PBMCs) [133]. Their application to CTCs, however, has been relatively limited due to the inefficiency of bead-cell pairing and the inevitable contamination of blood cells even in primarily enriched samples [134]. To overcome these limitations, Cheng et al. have recently developed Hydro-seq, which enable high-throughput contamination-free scRNA-seq of CTCs from breast cancer patients, uncovering cellular heterogeneity in metastasis and therapy related genes [134]. Having the scale-up capability while achieving high cell-capture efficiency and high-fidelity single-cell sequencing results, these technologies will play an increasingly important role in future studies aiming to generate more accurate and reproducible data at high throughput with low cost.

\subsection{Multidimensional Measurements}

While others have attributed the appearance of $\mathrm{CK}^{+} \mathrm{CD}_{4} 5^{+}$cells to false-positive $\mathrm{CK}^{+}$staining of WBCs [32], such "double-positive" cells may have functional roles or clinical implication within circulation given their occurrence at a much lower frequency in healthy blood samples [135]. Similarly, the exact role of apoptotic CTCs (e.g., $\mathrm{CK}^{+} \mathrm{CD} 45^{-}$cells with abnormal chromosomal patterns and/or nuclear fragmentation), $\mathrm{PD}-\mathrm{L1}^{+} \mathrm{CD}^{+} 5^{-}$cells, and $\mathrm{CK}^{-} \mathrm{CD} 45^{-}$cells in metastasis is not yet fully clear. Technologies enabling joint profiling of multiple modalities from the same individual cell may provide accurate means to understand clinical implication on the occurrence of these specific CTC subpopulations in circulation.

The high definition-CTC (HD-CTC) is an exemplary technology that facilitates real-time single-cell characterization of morphometric (i.e., cell roundness, cell area, AR subcellular localization) and protein expression changes in AR for prostate cancer [27]. Similarly, the functional EPISPOT assay, 
which is now named EPIDROP, allows simultaneous single-cell analysis of proteome and secretome of viable CTCs or of CTC clusters [136]. Such functional assays or microfluidic technologies, which have been successfully applied to patient-derived CTCs for analysis of genome [44], transcriptome [4], proteome [137], metabolome [138], and secretome [139] at the single-cell level, may further be integrated into the framework for deriving multidimensional data. Along with the increasingly available genomic data derived from tissue biopsies spanning diverse cancer types [140,141], the combined analysis of tissue and liquid biopsies may further uncover new insights into tumor heterogeneity and provide additional clinical information, as recently shown in lung cancer [4].

\section{Conclusions}

Recent scCTC studies have focused on how best to (1) identify and isolate extremely heterogeneous, fragile, and rare CTCs in a highly specific and unbiased manner, (2) discriminate false negatives and detect actionable mutations, and (3) relate the findings to clinically meaningful outcomes that could not have been caught by a tissue biopsy. Emerging data pointing towards the prevalence of CTC subpopulations and their differing metastatic potential have further stimulated studies aiming to identify and genetically/phenotypically characterize such premetastatic subsets of CTC populations that are favored to be liberated from primary tumors, survive in the bloodstream, and succeed in the early colonization phases.

While past efforts in deconvoluting the complex nature of CTCs have been largely ineffective with bulk-cell analysis, single-cell approaches are beginning to unmask cellular heterogeneity of CTCs and their clinical significance, providing a foundation for liquid biopsy in the clinic. As we continue to develop sensitive CTC enrichment technologies and generate more sequencing data from patient-derived CTCs, clinicians will continue to find a better way to apply liquid biopsies, possibly (1) at initial diagnosis, for prognostication, (2) after tumor resection, for assessment of residual disease, and (3) after adjuvant therapies, for prediction of early recurrence or relapse. With mounting molecular evidence suggesting prognostic value of CTC-derived biomarkers predictive of response to chemotherapy, targeted therapy, and immune checkpoint inhibitors, we anticipate that, in the near future, liquid biopsies will become a routine screening and monitoring of cancer patients.

Author Contributions: Conceptualization, S.B.L., C.T.L., and W.-T.L.; writing-original draft preparation, S.B.L.; writing-review and editing, S.B.L., C.T.L., and W.-T.L.; visualization, S.B.L.; supervision, C.T.L. and W.-T.L.; project administration, W.-T.L.; funding acquisition, W.-T.L.

Funding: This research was funded by the National Medical Research Council (NMRC), NMRC/CSA/040/2012 and NMRC/CSA-INV/0025/2017.

Acknowledgments: This work was carried out at the MechanoBioengineering Laboratory at the Department of Biomedical Engineering, National University of Singapore (NUS). The authors thank support provided by the Institute for Health Innovation and Technology (iHealthtech) at NUS. S.B.L. acknowledges support provided by NUS Graduate School for Integrative Sciences and Engineering (NGS), Mogam Science Scholarship Foundation, and Daewoong Foundation.

Conflicts of Interest: C.T.L. serves as an advisor of Biolidics. C.T.L. and W.-T.L. are shareholders of Biolidics. The remaining author declares no competing interest.

\section{References}

1. Fidler, I.J.; Hart, I.R. Biological diversity in metastatic neoplasms: Origins and implications. Science 1982, 217, 998-1003. [CrossRef] [PubMed]

2. Tirosh, I.; Suvà, M.L. Deciphering Human Tumor Biology by Single-Cell Expression Profiling. Annu. Rev. Cancer Biol. 2019, 3, 151-166. [CrossRef]

3. Shi, X.; Chakraborty, P.; Chaudhuri, A. Unmasking tumor heterogeneity and clonal evolution by single-cell analysis. J. Cancer Metastasis Treat. 2018, 4, 47. [CrossRef]

4. Lim, S.B.; Yeo, T.; Lee, W.D.; Bhagat, A.A.S.; Tan, S.J.; Tan, D.S.W.; Lim, W.T.; Lim, C.T. Addressing cellular heterogeneity in tumor and circulation for refined prognostication. Proc. Natl. Acad. Sci. USA 2019, 116, 17957-17962. [CrossRef] 
5. Lim, S.B.; Tan, S.J.; Lim, W.T.; Lim, C.T. An extracellular matrix-related prognostic and predictive indicator for early-stage non-small cell lung cancer. Nat. Commun. 2017, 8, 1734. [CrossRef]

6. Lim, S.B.; Lim, C.T.; Lim, D.W.-T. MO2-6-3Matrisomal abnormality: A predictive biomarker for cancer immunotherapy. Ann. Oncol. 2019, 30. [CrossRef]

7. Lim, S.B.; Chua, M.L.K.; Yeong, J.P.S.; Tan, S.J.; Lim, W.-T.; Lim, C.T. Pan-cancer analysis connects tumor matrisome to immune response. NPJ Precis. Oncol. 2019, 3, 15. [CrossRef]

8. Francart, M.E.; Lambert, J.; Vanwynsberghe, A.M.; Thompson, E.W.; Bourcy, M.; Polette, M.; Gilles, C. Epithelial-mesenchymal plasticity and circulating tumor cells: Travel companions to metastases. Dev. Dyn. 2018, 247, 432-450. [CrossRef]

9. Menon, N.V.; Lim, S.B.; Lim, C.T. Microfluidics for personalized drug screening of cancer. Curr. Opin. Pharmacol. 2019, 48, 155-161. [CrossRef]

10. Koh, Y.; Yagi, S.; Akamatsu, H.; Kanai, K.; Hayata, A.; Tokudome, N.; Akamatsu, K.; Higuchi, M.; Kanbara, H.; Nakanishi, M.; et al. Heterogeneous Expression of Programmed Death Receptor-ligand 1 on Circulating Tumor Cells in Patients with Lung Cancer. Clin. Lung Cancer 2019, 20, 270-277.e271. [CrossRef]

11. Grillet, F.; Bayet, E.; Villeronce, O.; Zappia, L.; Lagerqvist, E.L.; Lunke, S.; Charafe-Jauffret, E.; Pham, K.; Molck, C.; Rolland, N.; et al. Circulating tumour cells from patients with colorectal cancer have cancer stem cell hallmarks in ex vivo culture. Gut 2017, 66, 1802. [CrossRef] [PubMed]

12. Jordan, N.V.; Bardia, A.; Wittner, B.S.; Benes, C.; Ligorio, M.; Zheng, Y.; Yu, M.; Sundaresan, T.K.; Licausi, J.A.; Desai, R.; et al. HER2 expression identifies dynamic functional states within circulating breast cancer cells. Nature 2016, 537, 102-106. [CrossRef] [PubMed]

13. Agnoletto, C.; Corra, F.; Minotti, L.; Baldassari, F.; Crudele, F.; Cook, W.J.J.; Di Leva, G.; d'Adamo, A.P.; Gasparini, P.; Volinia, S. Heterogeneity in Circulating Tumor Cells: The Relevance of the Stem-Cell Subset. Cancers 2019, 11, 483. [CrossRef] [PubMed]

14. Lim, S.B.; Di Lee, W.; Vasudevan, J.; Lim, W.-T.; Lim, C.T. Liquid biopsy: One cell at a time. NPJ Precis. Oncol. 2019, 3, 23. [CrossRef]

15. Racila, E.; Euhus, D.; Weiss, A.J.; Rao, C.; McConnell, J.; Terstappen, L.W.M.M.; Uhr, J.W. Detection and characterization of carcinoma cells in the blood. Proc. Natl. Acad. Sci. USA 1998, 95, 4589. [CrossRef]

16. Heitzer, E.; Auer, M.; Gasch, C.; Pichler, M.; Ulz, P.; Hoffmann, E.M.; Lax, S.; Waldispuehl-Geigl, J.; Mauermann, O.; Lackner, C.; et al. Complex tumor genomes inferred from single circulating tumor cells by array-CGH and next-generation sequencing. Cancer Res. 2013, 73, 2965-2975. [CrossRef]

17. Lambros, M.B.; Seed, G.; Sumanasuriya, S.; Gil, V.; Crespo, M.; Fontes, M.; Chandler, R.; Mehra, N.; Fowler, G.; Ebbs, B.; et al. Single-Cell Analyses of Prostate Cancer Liquid Biopsies Acquired by Apheresis. Clin. Cancer Res. 2018, 24, 5635-5644. [CrossRef]

18. Pestrin, M.; Salvianti, F.; Galardi, F.; De Luca, F.; Turner, N.; Malorni, L.; Pazzagli, M.; Di Leo, A.; Pinzani, P. Heterogeneity of PIK3CA mutational status at the single cell level in circulating tumor cells from metastatic breast cancer patients. Mol. Oncol. 2015, 9, 749-757. [CrossRef]

19. Wang, Y.; Guo, L.; Feng, L.; Zhang, W.; Xiao, T.; Di, X.; Chen, G.; Zhang, K. Single nucleotide variant profiles of viable single circulating tumour cells reveal CTC behaviours in breast cancer. Oncol. Rep. 2018, 39, 2147-2159. [CrossRef]

20. Yin, J.; Wang, Z.; Li, G.; Lin, F.; Shao, K.; Cao, B.; Hou, Y. Characterization of circulating tumor cells in breast cancer patients by spiral microfluidics. Cell Biol. Toxicol. 2019, 35, 59-66. [CrossRef]

21. Lohr, J.G.; Kim, S.; Gould, J.; Knoechel, B.; Drier, Y.; Cotton, M.J.; Gray, D.; Birrer, N.; Wong, B.; Ha, G.; et al. Genetic interrogation of circulating multiple myeloma cells at single-cell resolution. Sci. Transl. Med. 2016, 8, 363ra147. [CrossRef] [PubMed]

22. Park, S.M.; Wong, D.J.; Ooi, C.C.; Kurtz, D.M.; Vermesh, O.; Aalipour, A.; Suh, S.; Pian, K.L.; Chabon, J.J.; Lee, S.H.; et al. Molecular profiling of single circulating tumor cells from lung cancer patients. Proc. Natl. Acad. Sci. USA 2016, 113, E8379-E8386. [CrossRef] [PubMed]

23. Kanwar, N.; Hu, P.; Bedard, P.; Clemons, M.; McCready, D.; Done, S.J. Identification of genomic signatures in circulating tumor cells from breast cancer. Int. J. Cancer 2015, 137, 332-344. [CrossRef] [PubMed]

24. Lohr, J.G.; Adalsteinsson, V.A.; Cibulskis, K.; Choudhury, A.D.; Rosenberg, M.; Cruz-Gordillo, P.; Francis, J.M.; Zhang, C.-Z.; Shalek, A.K.; Satija, R.; et al. Whole-exome sequencing of circulating tumor cells provides a window into metastatic prostate cancer. Nat. Biotechnol. 2014, 32, 479-484. [CrossRef] 
25. Greene, S.B.; Dago, A.E.; Leitz, L.J.; Wang, Y.; Lee, J.; Werner, S.L.; Gendreau, S.; Patel, P.; Jia, S.; Zhang, L.; et al. Chromosomal Instability Estimation Based on Next Generation Sequencing and Single Cell Genome Wide Copy Number Variation Analysis. PLoS ONE 2016, 11, e0165089. [CrossRef] [PubMed]

26. Jiang, R.; Lu, Y.-T.; Ho, H.; Li, B.; Chen, J.-F.; Lin, M.; Li, F.; Wu, K.; Wu, H.; Lichterman, J.; et al. A comparison of isolated circulating tumor cells and tissue biopsies using whole-genome sequencing in prostate cancer. Oncotarget 2015, 6, 44781-44793. [CrossRef]

27. Dago, A.E.; Stepansky, A.; Carlsson, A.; Luttgen, M.; Kendall, J.; Baslan, T.; Kolatkar, A.; Wigler, M.; Bethel, K.; Gross, M.E.; et al. Rapid phenotypic and genomic change in response to therapeutic pressure in prostate cancer inferred by high content analysis of single circulating tumor cells. PLoS ONE 2014, 9, e101777. [CrossRef]

28. Deng, G.; Krishnakumar, S.; Powell, A.A.; Zhang, H.; Mindrinos, M.N.; Telli, M.L.; Davis, R.W.; Jeffrey, S.S. Single cell mutational analysis of PIK3CA in circulating tumor cells and metastases in breast cancer reveals heterogeneity, discordance, and mutation persistence in cultured disseminated tumor cells from bone marrow. BMC Cancer 2014, 14, 456. [CrossRef]

29. Fernandez, S.V.; Bingham, C.; Fittipaldi, P.; Austin, L.; Palazzo, J.; Palmer, G.; Alpaugh, K.; Cristofanilli, M. TP53 mutations detected in circulating tumor cells present in the blood of metastatic triple negative breast cancer patients. Breast Cancer Res. 2014, 16, 445. [CrossRef]

30. Polzer, B.; Medoro, G.; Pasch, S.; Fontana, F.; Zorzino, L.; Pestka, A.; Andergassen, U.; Meier-Stiegen, F.; Czyz, Z.T.; Alberter, B.; et al. Molecular profiling of single circulating tumor cells with diagnostic intention. EMBO Mol. Med. 2014, 6, 1371-1386. [CrossRef]

31. De Luca, F.; Rotunno, G.; Salvianti, F.; Galardi, F.; Pestrin, M.; Gabellini, S.; Simi, L.; Mancini, I.; Vannucchi, A.M.; Pazzagli, M.; et al. Mutational analysis of single circulating tumor cells by next generation sequencing in metastatic breast cancer. Oncotarget 2016, 7, 26107-26119. [CrossRef] [PubMed]

32. Fischer, J.C.; Niederacher, D.; Topp, S.A.; Honisch, E.; Schumacher, S.; Schmitz, N.; Zacarias Fohrding, L.; Vay, C.; Hoffmann, I.; Kasprowicz, N.S.; et al. Diagnostic leukapheresis enables reliable detection of circulating tumor cells of nonmetastatic cancer patients. Proc. Natl. Acad. Sci. USA 2013, 110, 16580-16585. [CrossRef] [PubMed]

33. Neves, R.P.; Raba, K.; Schmidt, O.; Honisch, E.; Meier-Stiegen, F.; Behrens, B.; Mohlendick, B.; Fehm, T.; Neubauer, H.; Klein, C.A.; et al. Genomic high-resolution profiling of single CKpos/CD45neg flow-sorting purified circulating tumor cells from patients with metastatic breast cancer. Clin. Chem. 2014, 60, 1290-1297. [CrossRef] [PubMed]

34. Vishnoi, M.; Peddibhotla, S.; Yin, W.; Scamardo, A.T.; George, G.C.; Hong, D.S.; Marchetti, D. The isolation and characterization of CTC subsets related to breast cancer dormancy. Sci. Rep. 2015, 5, 17533. [CrossRef] [PubMed]

35. Gasch, C.; Oldopp, T.; Mauermann, O.; Gorges, T.M.; Andreas, A.; Coith, C.; Muller, V.; Fehm, T.; Janni, W.; Pantel, K.; et al. Frequent detection of PIK3CA mutations in single circulating tumor cells of patients suffering from HER2-negative metastatic breast cancer. Mol. Oncol. 2016, 10, 1330-1343. [CrossRef] [PubMed]

36. Shaw, J.A.; Guttery, D.S.; Hills, A.; Fernandez-Garcia, D.; Page, K.; Rosales, B.M.; Goddard, K.S.; Hastings, R.K.; Luo, J.; Ogle, O.; et al. Mutation Analysis of Cell-Free DNA and Single Circulating Tumor Cells in Metastatic Breast Cancer Patients with High Circulating Tumor Cell Counts. Clin. Cancer Res. 2017, 23, 88-96. [CrossRef] [PubMed]

37. Neumann, M.H.D.; Schneck, H.; Decker, Y.; Schömer, S.; Franken, A.; Endris, V.; Pfarr, N.; Weichert, W.; Niederacher, D.; Fehm, T.; et al. Isolation and characterization of circulating tumor cells using a novel workflow combining the CellSearch@system and the CellCelector ${ }^{\mathrm{TM}}$. Biotechnol. Prog. 2017, 33, 125-132. [CrossRef]

38. Bingham, C.; Fernandez, S.V.; Fittipaldi, P.; Dempsey, P.W.; Ruth, K.J.; Cristofanilli, M.; Katherine Alpaugh, R. Mutational studies on single circulating tumor cells isolated from the blood of inflammatory breast cancer patients. Breast Cancer Res. Treat. 2017, 163, 219-230. [CrossRef]

39. Babayan, A.; Hannemann, J.; Spotter, J.; Muller, V.; Pantel, K.; Joosse, S.A. Heterogeneity of estrogen receptor expression in circulating tumor cells from metastatic breast cancer patients. PLoS ONE 2013, 8, e75038. [CrossRef] 
40. Heidary, M.; Auer, M.; Ulz, P.; Heitzer, E.; Petru, E.; Gasch, C.; Riethdorf, S.; Mauermann, O.; Lafer, I.; Pristauz, G.; et al. The dynamic range of circulating tumor DNA in metastatic breast cancer. Breast Cancer Res. 2014, 16, 421. [CrossRef]

41. Mu, Z.; Benali-Furet, N.; Uzan, G.; Znaty, A.; Ye, Z.; Paolillo, C.; Wang, C.; Austin, L.; Rossi, G.; Fortina, P.; et al. Detection and Characterization of Circulating Tumor Associated Cells in Metastatic Breast Cancer. Int. J. Mol. Sci. 2016, 17, 1665. [CrossRef] [PubMed]

42. Carter, L.; Rothwell, D.G.; Mesquita, B.; Smowton, C.; Leong, H.S.; Fernandez-Gutierrez, F.; Li, Y.; Burt, D.J.; Antonello, J.; Morrow, C.J.; et al. Molecular analysis of circulating tumor cells identifies distinct copy-number profiles in patients with chemosensitive and chemorefractory small-cell lung cancer. Nat. Med. 2017, 23, 114-119. [CrossRef] [PubMed]

43. Ni, X.; Zhuo, M.; Su, Z.; Duan, J.; Gao, Y.; Wang, Z.; Zong, C.; Bai, H.; Chapman, A.R.; Zhao, J.; et al. Reproducible copy number variation patterns among single circulating tumor cells of lung cancer patients. Proc. Natl. Acad. Sci. USA 2013, 110, 21083-21088. [CrossRef] [PubMed]

44. Yeo, T.; Tan, S.J.; Lim, C.L.; Lau, D.P.; Chua, Y.W.; Krisna, S.S.; Iyer, G.; Tan, G.S.; Lim, T.K.; Tan, D.S.; et al. Microfluidic enrichment for the single cell analysis of circulating tumor cells. Sci. Rep. 2016, 6, 22076. [CrossRef]

45. Gao, Y.; Ni, X.; Guo, H.; Su, Z.; Ba, Y.; Tong, Z.; Guo, Z.; Yao, X.; Chen, X.; Yin, J.; et al. Single-cell sequencing deciphers a convergent evolution of copy number alterations from primary to circulating tumor cells. Genome Res. 2017, 27, 1312-1322. [CrossRef]

46. Su, Z.; Wang, Z.; Ni, X.; Duan, J.; Gao, Y.; Zhuo, M.; Li, R.; Zhao, J.; Ma, Q.; Bai, H.; et al. Inferring the Evolution and Progression of Small-Cell Lung Cancer by Single-Cell Sequencing of Circulating Tumor Cells. Clin. Cancer Res. 2019, 25, 5049-5060. [CrossRef]

47. Steinert, G.; Schölch, S.; Niemietz, T.; Iwata, N.; García, S.A.; Behrens, B.; Voigt, A.; Kloor, M.; Benner, A.; Bork, U.; et al. Immune Escape and Survival Mechanisms in Circulating Tumor Cells of Colorectal Cancer. Cancer Res. 2014, 74, 1694-1704. [CrossRef]

48. Gasch, C.; Bauernhofer, T.; Pichler, M.; Langer-Freitag, S.; Reeh, M.; Seifert, A.M.; Mauermann, O.; Izbicki, J.R.; Pantel, K.; Riethdorf, S. Heterogeneity of epidermal growth factor receptor status and mutations of KRAS/PIK3CA in circulating tumor cells of patients with colorectal cancer. Clin. Chem. 2013, 59, 252-260. [CrossRef]

49. Fabbri, F.; Carloni, S.; Zoli, W.; Ulivi, P.; Gallerani, G.; Fici, P.; Chiadini, E.; Passardi, A.; Frassineti, G.L.; Ragazzini, A.; et al. Detection and recovery of circulating colon cancer cells using a dielectrophoresis-based device: KRAS mutation status in pure CTCs. Cancer Lett. 2013, 335, 225-231. [CrossRef]

50. Sakaizawa, K.; Goto, Y.; Kiniwa, Y.; Uchiyama, A.; Harada, K.; Shimada, S.; Saida, T.; Ferrone, S.; Takata, M.; Uhara, H.; et al. Mutation analysis of BRAF and KIT in circulating melanoma cells at the single cell level. Br. J. Cancer 2012, 106, 939-946. [CrossRef]

51. Kiniwa, Y.; Nakamura, K.; Mikoshiba, A.; Akiyama, Y.; Morimoto, A.; Okuyama, R. Diversity of circulating tumor cells in peripheral blood: Detection of heterogeneous BRAF mutations in a patient with advanced melanoma by single-cell analysis. J. Derm. Sci. 2018, 90, 211-213. [CrossRef] [PubMed]

52. Anantharaman, A.; Friedlander, T.; Lu, D.; Krupa, R.; Premasekharan, G.; Hough, J.; Edwards, M.; Paz, R.; Lindquist, K.; Graf, R.; et al. Programmed death-ligand 1 (PD-L1) characterization of circulating tumor cells (CTCs) in muscle invasive and metastatic bladder cancer patients. BMC Cancer 2016, 16, 744. [CrossRef] [PubMed]

53. Court, C.M.; Ankeny, J.S.; Sho, S.; Hou, S.; Li, Q.; Hsieh, C.; Song, M.; Liao, X.; Rochefort, M.M.; Wainberg, Z.A.; et al. Reality of Single Circulating Tumor Cell Sequencing for Molecular Diagnostics in Pancreatic Cancer. J. Mol. Diagn. 2016, 18, 688-696. [CrossRef] [PubMed]

54. Pantel, K.; Deneve, E.; Nocca, D.; Coffy, A.; Vendrell, J.P.; Maudelonde, T.; Riethdorf, S.; Alix-Panabieres, C. Circulating epithelial cells in patients with benign colon diseases. Clin. Chem. 2012, 58, 936-940. [CrossRef]

55. Zhang, L.; Ridgway, L.D.; Wetzel, M.D.; Ngo, J.; Yin, W.; Kumar, D.; Goodman, J.C.; Groves, M.D.; Marchetti, D. The identification and characterization of breast cancer CTCs competent for brain metastasis. Sci. Transl. Med. 2013, 5, 180ra148. [CrossRef]

56. Lee, Y.; Guan, G.; Bhagat, A.A. ClearCell@FX, a label-free microfluidics technology for enrichment of viable circulating tumor cells. Cytom. Part. A 2018, 93, 1251-1254. [CrossRef] 
57. Ligthart, S.T.; Coumans, F.A.; Bidard, F.C.; Simkens, L.H.; Punt, C.J.; de Groot, M.R.; Attard, G.; de Bono, J.S.; Pierga, J.Y.; Terstappen, L.W. Circulating Tumor Cells Count and Morphological Features in Breast, Colorectal and Prostate Cancer. PLoS ONE 2013, 8, e67148. [CrossRef]

58. Kallergi, G.; Konstantinidis, G.; Markomanolaki, H.; Papadaki, M.A.; Mavroudis, D.; Stournaras, C.; Georgoulias, V.; Agelaki, S. Apoptotic circulating tumor cells in early and metastatic breast cancer patients. Mol. Cancer Ther. 2013, 12, 1886-1895. [CrossRef]

59. Blainey, P.C. The future is now: Single-cell genomics of bacteria and archaea. FEMS Microbiol. Rev. 2013, 37, 407-427. [CrossRef]

60. Salvianti, F.; Pazzagli, M.; Pinzani, P. Single circulating tumor cell sequencing as an advanced tool in cancer management. Expert Rev. Mol. Diagn. 2016, 16, 51-63. [CrossRef]

61. Swennenhuis, J.F.; Reumers, J.; Thys, K.; Aerssens, J.; Terstappen, L.W. Efficiency of whole genome amplification of single circulating tumor cells enriched by CellSearch and sorted by FACS. Genome Med. 2013, 5, 106. [CrossRef] [PubMed]

62. Gawad, C.; Koh, W.; Quake, S.R. Single-cell genome sequencing: Current state of the science. Nat. Rev. Genet. 2016, 17, 175-188. [CrossRef] [PubMed]

63. Pao, W.; Girard, N. New driver mutations in non-small-cell lung cancer. Lancet Oncol. 2011, 12, $175-180$. [CrossRef]

64. Stephens, P.J.; Tarpey, P.S.; Davies, H.; Van Loo, P.; Greenman, C.; Wedge, D.C.; Nik-Zainal, S.; Martin, S.; Varela, I.; Bignell, G.R.; et al. The landscape of cancer genes and mutational processes in breast cancer. Nature 2012, 486, 400-404. [CrossRef] [PubMed]

65. Jhawer, M.; Goel, S.; Wilson, A.J.; Montagna, C.; Ling, Y.H.; Byun, D.S.; Nasser, S.; Arango, D.; Shin, J.; Klampfer, L.; et al. PIK3CA mutation/PTEN expression status predicts response of colon cancer cells to the epidermal growth factor receptor inhibitor cetuximab. Cancer Res. 2008, 68, 1953-1961. [CrossRef] [PubMed]

66. Berns, K.; Horlings, H.M.; Hennessy, B.T.; Madiredjo, M.; Hijmans, E.M.; Beelen, K.; Linn, S.C.; Gonzalez-Angulo, A.M.; Stemke-Hale, K.; Hauptmann, M.; et al. A Functional Genetic Approach Identifies the PI3K Pathway as a Major Determinant of Trastuzumab Resistance in Breast Cancer. Cancer Cell 2007, 12, 395-402. [CrossRef] [PubMed]

67. Chandarlapaty, S.; Sakr, R.A.; Giri, D.; Patil, S.; Heguy, A.; Morrow, M.; Modi, S.; Norton, L.; Rosen, N.; Hudis, C.; et al. Frequent mutational activation of the PI3K-AKT pathway in trastuzumab-resistant breast cancer. Clin. Cancer Res. 2012, 18, 6784-6791. [CrossRef]

68. Mukohara, T. Mechanisms of resistance to anti-human epidermal growth factor receptor 2 agents in breast cancer. Cancer Sci. 2011, 102, 1-8. [CrossRef]

69. Ibrahim, E.M.; Kazkaz, G.A.; Al-Mansour, M.M.; Al-Foheidi, M.E. The predictive and prognostic role of phosphatase phosphoinositol-3 (PI3) kinase (PIK3CA) mutation in HER2-positive breast cancer receiving HER2-targeted therapy: A meta-analysis. Breast Cancer Res. Treat. 2015, 152, 463-476. [CrossRef]

70. Loibl, S.; von Minckwitz, G.; Schneeweiss, A.; Paepke, S.; Lehmann, A.; Rezai, M.; Zahm, D.M.; Sinn, P.; Khandan, F.; Eidtmann, H.; et al. PIK3CA mutations are associated with lower rates of pathologic complete response to anti-human epidermal growth factor receptor 2 (her2) therapy in primary HER2-overexpressing breast cancer. J. Clin. Oncol. 2014, 32, 3212-3220. [CrossRef]

71. Neumann, M.; Decker, Y.; Franken, A.; Schömer, S.; Schneck, H.; Fehm, T.; Weichert, W.; Endriss, V.; Neubauer, H.; Niederacher, D. Sequential analysis of circulating tumor cells on genome and protein level: Potential regulation of the invasion marker CapG by PIK3CA. Senologie Zeitschrift für Mammadiagnostik und Herapie 2016, 13, A95. [CrossRef]

72. Janku, F.; Wheler, J.J.; Westin, S.N.; Moulder, S.L.; Naing, A.; Tsimberidou, A.M.; Fu, S.; Falchook, G.S.; Hong, D.S.; Garrido-Laguna, I.; et al. PI3K/AKT/mTOR inhibitors in patients with breast and gynecologic malignancies harboring PIK3CA mutations. J. Clin. Oncol. 2012, 30, 777-782. [CrossRef] [PubMed]

73. Olivier, M.; Eeles, R.; Hollstein, M.; Khan, M.A.; Harris, C.C.; Hainaut, P. The IARC TP53 database: New online mutation analysis and recommendations to users. Hum. Mutat. 2002, 19, 607-614. [CrossRef] [PubMed]

74. Kim, T.; Veronese, A.; Pichiorri, F.; Lee, T.J.; Jeon, Y.-J.; Volinia, S.; Pineau, P.; Marchio, A.; Palatini, J.; Suh, S.-S.; et al. p53 regulates epithelial-mesenchymal transition through microRNAs targeting ZEB1 and ZEB2. J. Exp. Med. 2011, 208, 875. [CrossRef] 
75. Chang, C.-J.; Chao, C.-H.; Xia, W.; Yang, J.-Y.; Xiong, Y.; Li, C.-W.; Yu, W.-H.; Rehman, S.K.; Hsu, J.L.; Lee, H.-H.; et al. p53 regulates epithelial-mesenchymal transition and stem cell properties through modulating miRNAs. Nat. Cell Biol. 2011, 13,317-323. [CrossRef]

76. Petitjean, A.; Achatz, M.I.; Borresen-Dale, A.L.; Hainaut, P.; Olivier, M. TP53 mutations in human cancers: Functional selection and impact on cancer prognosis and outcomes. Oncogene 2007, 26, 2157-2165. [CrossRef]

77. Li, J.; Yang, L.; Gaur, S.; Zhang, K.; Wu, X.; Yuan, Y.-C.; Li, H.; Hu, S.; Weng, Y.; Yen, Y. Mutants TP53 p.R273H and p.R273C but not p.R273G Enhance Cancer Cell Malignancy. Hum. Mutat. 2014, 35, 575-584. [CrossRef]

78. Kalemkerian, G.P. Chemotherapy for small-cell lung cancer. Lancet Oncol. 2014, 15, 13-14. [CrossRef]

79. Sutherland, K.D.; Proost, N.; Brouns, I.; Adriaensen, D.; Song, J.Y.; Berns, A. Cell of origin of small cell lung cancer: Inactivation of Trp53 and Rb1 in distinct cell types of adult mouse lung. Cancer Cell 2011, 19, 754-764. [CrossRef]

80. Nicholson, R.I.; Gee, J.M.; Harper, M.E. EGFR and cancer prognosis. Eur. J. Cancer 2001, 37 (Suppl. S4), S9-S15. [CrossRef]

81. Ciardiello, F.; Tortora, G. Epidermal growth factor receptor (EGFR) as a target in cancer therapy: Understanding the role of receptor expression and other molecular determinants that could influence the response to anti-EGFR drugs. Eur. J. Cancer 2003, 39, 1348-1354. [CrossRef]

82. Moroni, M.; Veronese, S.; Benvenuti, S.; Marrapese, G.; Sartore-Bianchi, A.; Di Nicolantonio, F.; Gambacorta, M.; Siena, S.; Bardelli, A. Gene copy number for epidermal growth factor receptor (EGFR) and clinical response to antiEGFR treatment in colorectal cancer: A cohort study. Lancet Oncol. 2005, 6, 279-286. [CrossRef]

83. Lièvre, A.; Bachet, J.-B.; Le Corre, D.; Boige, V.; Landi, B.; Emile, J.-F.; Côté, J.-F.; Tomasic, G.; Penna, C.; Ducreux, M.; et al. KRAS Mutation Status Is Predictive of Response to Cetuximab Therapy in Colorectal Cancer. Cancer Res. 2006, 66, 3992. [CrossRef]

84. Amado, R.G.; Wolf, M.; Peeters, M.; Van Cutsem, E.; Siena, S.; Freeman, D.J.; Juan, T.; Sikorski, R.; Suggs, S.; Radinsky, R.; et al. Wild-Type KRAS Is Required for Panitumumab Efficacy in Patients with Metastatic Colorectal Cancer. J. Clin. Oncol. 2008, 26, 1626-1634. [CrossRef]

85. Zhu, C.-Q.; da Cunha Santos, G.; Ding, K.; Sakurada, A.; Cutz, J.-C.; Liu, N.; Zhang, T.; Marrano, P.; Whitehead, M.; Squire, J.A.; et al. Role of KRAS and EGFR as Biomarkers of Response to Erlotinib in National Cancer Institute of Canada Clinical Trials Group Study BR.21. J. Clin. Oncol. 2008, 26, 4268-4275. [CrossRef]

86. Watanabe, T.; Kobunai, T.; Yamamoto, Y.; Matsuda, K.; Ishihara, S.; Nozawa, K.; Iinuma, H.; Shibuya, H.; Eshima, K. Heterogeneity of KRAS Status May Explain the Subset of Discordant KRAS Status Between Primary and Metastatic Colorectal Cancer. Dis. Colon Rectum 2011, 54, 1170-1178. [CrossRef]

87. Ducreux, M.; Chamseddine, A.; Laurent-Puig, P.; Smolenschi, C.; Hollebecque, A.; Dartigues, P.; Samallin, E.; Boige, V.; Malka, D.; Gelli, M. Molecular targeted therapy of BRAF-mutant colorectal cancer. Ther. Adv. Med. Oncol. 2019, 11. [CrossRef]

88. Marconcini, R.; Galli, L.; Antonuzzo, A.; Bursi, S.; Roncella, C.; Fontanini, G.; Sensi, E.; Falcone, A. Metastatic BRAF K601E-mutated melanoma reaches complete response to MEK inhibitor trametinib administered for over 36 months. Exp. Hematol. Oncol. 2017, 6, 6. [CrossRef]

89. Mostert, B.; Jiang, Y.; Sieuwerts, A.M.; Wang, H.; Bolt-de Vries, J.; Biermann, K.; Kraan, J.; Lalmahomed, Z.; van Galen, A.; de Weerd, V.; et al. KRAS and BRAF mutation status in circulating colorectal tumor cells and their correlation with primary and metastatic tumor tissue. Int. J. Cancer 2013, 133, 130-141. [CrossRef]

90. Wheeler, J.M.; Bodmer, W.F.; Mortensen, N.J. DNA mismatch repair genes and colorectal cancer. Gut 2000, 47, 148-153. [CrossRef]

91. Mackay, H.J.; Gallinger, S.; Tsao, M.S.; McLachlin, C.M.; Tu, D.; Keiser, K.; Eisenhauer, E.A.; Oza, A.M. Prognostic value of microsatellite instability (MSI) and PTEN expression in women with endometrial cancer: Results from studies of the NCIC Clinical Trials Group (NCIC CTG). Eur. J. Cancer 2010, 46, 1365-1373. [CrossRef] [PubMed]

92. Popat, S.; Hubner, R.; Houlston, R.S. Systematic Review of Microsatellite Instability and Colorectal Cancer Prognosis. J. Clin. Oncol. 2005, 23, 609-618. [CrossRef] [PubMed]

93. Thibodeau, S.N.; Bren, G.; Schaid, D. Microsatellite instability in cancer of the proximal colon. Science 1993, 260, 816-819. [CrossRef] [PubMed] 
94. Kim, G.P.; Colangelo, L.H.; Wieand, H.S.; Paik, S.; Kirsch, I.R.; Wolmark, N.; Allegra, C.J.; National Cancer, I. Prognostic and predictive roles of high-degree microsatellite instability in colon cancer: A National Cancer Institute-National Surgical Adjuvant Breast and Bowel Project Collaborative Study. J. Clin. Oncol. 2007, 25, 767-772. [CrossRef] [PubMed]

95. Ribic, C.M.; Sargent, D.J.; Moore, M.J.; Thibodeau, S.N.; French, A.J.; Goldberg, R.M.; Hamilton, S.R.; Laurent-Puig, P.; Gryfe, R.; Shepherd, L.E.; et al. Tumor Microsatellite-Instability Status as a Predictor of Benefit from Fluorouracil-Based Adjuvant Chemotherapy for Colon Cancer. N. Engl. J. Med. 2003, 349, 247-257. [CrossRef]

96. Goldstein, J.; Tran, B.; Ensor, J.; Gibbs, P.; Wong, H.L.; Wong, S.F.; Vilar, E.; Tie, J.; Broaddus, R.; Kopetz, S.; et al. Multicenter retrospective analysis of metastatic colorectal cancer (CRC) with high-level microsatellite instability (MSI-H). Ann. Oncol. 2014, 25, 1032-1038. [CrossRef] [PubMed]

97. Findeisen, P.; Kloor, M.; Merx, S.; Sutter, C.; Woerner, S.M.; Dostmann, N.; Benner, A.; Dondog, B.; Pawlita, M.; Dippold, W.; et al. T25 repeat in the 3' untranslated region of the CASP2 gene: A sensitive and specific marker for microsatellite instability in colorectal cancer. Cancer Res. 2005, 65, 8072-8078. [CrossRef]

98. Carethers, J.M.; Smith, E.J.; Behling, C.A.; Nguyen, L.; Tajima, A.; Doctolero, R.T.; Cabrera, B.L.; Goel, A.; Arnold, C.A.; Miyai, K.; et al. Use of 5-fluorouracil and survival in patients with microsatellite-unstable colorectal cancer. Gastroenterology 2004, 126, 394-401. [CrossRef]

99. Boland, C.R.; Thibodeau, S.N.; Hamilton, S.R.; Sidransky, D.; Eshleman, J.R.; Burt, R.W.; Meltzer, S.J.; Rodriguez-Bigas, M.A.; Fodde, R.; Ranzani, G.N.; et al. A National Cancer Institute Workshop on Microsatellite Instability for cancer detection and familial predisposition: Development of international criteria for the determination of microsatellite instability in colorectal cancer. Cancer Res. 1998, 58, 5248-5257.

100. Bergamaschi, A.; Kim, Y.H.; Wang, P.; Sorlie, T.; Hernandez-Boussard, T.; Lonning, P.E.; Tibshirani, R.; Borresen-Dale, A.L.; Pollack, J.R. Distinct patterns of DNA copy number alteration are associated with different clinicopathological features and gene-expression subtypes of breast cancer. Genes Chromosomes Cancer 2006, 45, 1033-1040. [CrossRef]

101. Chin, K.; DeVries, S.; Fridlyand, J.; Spellman, P.T.; Roydasgupta, R.; Kuo, W.L.; Lapuk, A.; Neve, R.M.; Qian, Z.; Ryder, T.; et al. Genomic and transcriptional aberrations linked to breast cancer pathophysiologies. Cancer Cell 2006, 10, 529-541. [CrossRef] [PubMed]

102. Zhao, X.; Li, C.; Paez, J.G.; Chin, K.; Jänne, P.A.; Chen, T.-H.; Girard, L.; Minna, J.; Christiani, D.; Leo, C.; et al. An Integrated View of Copy Number and Allelic Alterations in the Cancer Genome Using Single Nucleotide Polymorphism Arrays. Cancer Res. 2004, 64, 3060. [CrossRef] [PubMed]

103. Cappuzzo, F.; Varella-Garcia, M.; Shigematsu, H.; Domenichini, I.; Bartolini, S.; Ceresoli, G.L.; Rossi, E.; Ludovini, V.; Gregorc, V.; Toschi, L.; et al. Increased HER2 Gene Copy Number Is Associated with Response to Gefitinib Therapy in Epidermal Growth Factor Receptor-Positive Non-Small-Cell Lung Cancer Patients. J. Clin. Oncol. 2005, 23, 5007-5018. [CrossRef]

104. Watkins, J.A.; Irshad, S.; Grigoriadis, A.; Tutt, A.N. Genomic scars as biomarkers of homologous recombination deficiency and drug response in breast and ovarian cancers. Breast Cancer Res. 2014, 16, 211. [CrossRef]

105. Humar, B.; Blair, V.; Charlton, A.; More, H.; Martin, I.; Guilford, P. E-cadherin deficiency initiates gastric signet-ring cell carcinoma in mice and man. Cancer Res. 2009, 69, 2050-2056. [CrossRef]

106. Takeuchi, T.; Adachi, Y.; Nagayama, T. A WWOX-binding molecule, transmembrane protein 207, is related to the invasiveness of gastric signet-ring cell carcinoma. Carcinogenesis 2012, 33, 548-554. [CrossRef]

107. Berger, M.F.; Lawrence, M.S.; Demichelis, F.; Drier, Y.; Cibulskis, K.; Sivachenko, A.Y.; Sboner, A.; Esgueva, R.; Pflueger, D.; Sougnez, C.; et al. The genomic complexity of primary human prostate cancer. Nature 2011, 470, 214-220. [CrossRef]

108. Baca, S.C.; Prandi, D.; Lawrence, M.S.; Mosquera, J.M.; Romanel, A.; Drier, Y.; Park, K.; Kitabayashi, N.; MacDonald, T.Y.; Ghandi, M.; et al. Punctuated Evolution of Prostate Cancer Genomes. Cell 2013, 153, 666-677. [CrossRef]

109. Budd, G.T.; Cristofanilli, M.; Ellis, M.J.; Stopeck, A.; Borden, E.; Miller, M.C.; Matera, J.; Repollet, M.; Doyle, G.V.; Terstappen, L.W.M.M.; et al. Circulating Tumor Cells versus Imaging-Predicting Overall Survival in Metastatic Breast Cancer. Clin. Cancer Res. 2006, 12, 6403. [CrossRef] 
110. Cohen, S.J.; Punt, C.J.A.; Iannotti, N.; Saidman, B.H.; Sabbath, K.D.; Gabrail, N.Y.; Picus, J.; Morse, M.; Mitchell, E.; Miller, M.C.; et al. Relationship of Circulating Tumor Cells to Tumor Response, Progression-Free Survival, and Overall Survival in Patients with Metastatic Colorectal Cancer. J. Clin. Oncol. 2008, 26, 3213-3221. [CrossRef]

111. De Bono, J.S.; Scher, H.I.; Montgomery, R.B.; Parker, C.; Miller, M.C.; Tissing, H.; Doyle, G.V.; Terstappen, L.W.; Pienta, K.J.; Raghavan, D. Circulating tumor cells predict survival benefit from treatment in metastatic castration-resistant prostate cancer. Clin. Cancer Res. 2008, 14, 6302-6309. [CrossRef] [PubMed]

112. Hayes, D.F.; Cristofanilli, M.; Budd, G.T.; Ellis, M.J.; Stopeck, A.; Miller, M.C.; Matera, J.; Allard, W.J.; Doyle, G.V.; Terstappen, L.W.W.M. Circulating Tumor Cells at Each Follow-up Time Point during Therapy of Metastatic Breast Cancer Patients Predict Progression-Free and Overall Survival. Clin. Cancer Res. 2006, 12, 4218. [CrossRef] [PubMed]

113. Miyamoto, D.T.; Lee, R.J.; Stott, S.L.; Ting, D.T.; Wittner, B.S.; Ulman, M.; Smas, M.E.; Lord, J.B.; Brannigan, B.W.; Trautwein, J.; et al. Androgen Receptor Signaling in Circulating Tumor Cells as a Marker of Hormonally Responsive Prostate Cancer. Cancer Discov. 2012, 2, 995. [CrossRef] [PubMed]

114. McArthur, G.A.; Chapman, P.B.; Robert, C.; Larkin, J.; Haanen, J.B.; Dummer, R.; Ribas, A.; Hogg, D.; Hamid, O.; Ascierto, P.A.; et al. Safety and efficacy of vemurafenib in BRAFV600E and BRAFV600K mutation-positive melanoma (BRIM-3): Extended follow-up of a phase 3, randomised, open-label study. Lancet Oncol. 2014, 15, 323-332. [CrossRef]

115. Cortés-Funes, H.; Mendiola, C.; Manso, L.; Ciruelos, E. Neratinib, an irreversible pan erB receptor tyrosine kinase inhibitor active for advanced HER2+breast cancer. Breast Cancer Res. 2009, 11, S19. [CrossRef]

116. Slamon, D.J.; Leyland-Jones, B.; Shak, S.; Fuchs, H.; Paton, V.; Bajamonde, A.; Fleming, T.; Eiermann, W.; Wolter, J.; Pegram, M.; et al. Use of Chemotherapy plus a Monoclonal Antibody against HER2 for Metastatic Breast Cancer That Overexpresses HER2. N. Engl. J. Med. 2001, 344, 783-792. [CrossRef]

117. Baselga, J.; Gelmon, K.A.; Verma, S.; Wardley, A.; Conte, P.; Miles, D.; Bianchi, G.; Cortes, J.; McNally, V.A.; Ross, G.A.; et al. Phase II Trial of Pertuzumab and Trastuzumab in Patients with Human Epidermal Growth Factor Receptor 2-Positive Metastatic Breast Cancer That Progressed During Prior Trastuzumab Therapy. J. Clin. Oncol. 2010, 28, 1138-1144. [CrossRef]

118. Zhou, C.; Wu, Y.-L.; Chen, G.; Feng, J.; Liu, X.-Q.; Wang, C.; Zhang, S.; Wang, J.; Zhou, S.; Ren, S.; et al. Erlotinib versus chemotherapy as first-line treatment for patients with advanced EGFR mutation-positive non-small-cell lung cancer (OPTIMAL, CTONG-0802): A multicentre, open-label, randomised, phase 3 study. Lancet Oncol. 2011, 12, 735-742. [CrossRef]

119. Bailey, R.; Kris, M.; Wolf, M.; Kay, A.; Averbuch, S.; Askaa, J.; Janas, M.; Schmidt, K.; Fukuoka, M. O-242 Gefitinib ('Iressa', ZD1839) monotherapy for pretreated advanced non-small-cell lung cancer in IDEAL 1 and 2: Tumor response is not clinically relevantly predictable from tumor EGFR membrane staining alone. Lung Cancer 2003, 41, S71. [CrossRef]

120. Amir, E.; Miller, N.; Geddie, W.; Freedman, O.; Kassam, F.; Simmons, C.; Oldfield, M.; Dranitsaris, G.; Tomlinson, G.; Laupacis, A.; et al. Prospective study evaluating the impact of tissue confirmation of metastatic disease in patients with breast cancer. J. Clin. Oncol. 2012, 30, 587-592. [CrossRef]

121. Lindström, L.S.; Karlsson, E.; Wilking, U.M.; Johansson, U.; Hartman, J.; Lidbrink, E.K.; Hatschek, T.; Skoog, L.; Bergh, J. Clinically Used Breast Cancer Markers Such as Estrogen Receptor, Progesterone Receptor, and Human Epidermal Growth Factor Receptor 2 Are Unstable Throughout Tumor Progression. J. Clin. Oncol. 2012, 30, 2601-2608. [CrossRef] [PubMed]

122. Turner, N.H.; Di Leo, A. HER2 discordance between primary and metastatic breast cancer: Assessing the clinical impact. Cancer Treat. Rev. 2013, 39, 947-957. [CrossRef]

123. Pusztai, L.; Viale, G.; Kelly, C.M.; Hudis, C.A. Estrogen and HER-2 Receptor Discordance Between Primary Breast Cancer and Metastasis. Oncologist 2010, 15, 1164-1168. [CrossRef] [PubMed]

124. Fehm, T.; Muller, V.; Aktas, B.; Janni, W.; Schneeweiss, A.; Stickeler, E.; Lattrich, C.; Lohberg, C.R.; Solomayer, E.; Rack, B.; et al. HER2 status of circulating tumor cells in patients with metastatic breast cancer: A prospective, multicenter trial. Breast Cancer Res. Treat. 2010, 124, 403-412. [CrossRef] [PubMed]

125. Wallwiener, M.; Hartkopf, A.D.; Riethdorf, S.; Nees, J.; Sprick, M.R.; Schonfisch, B.; Taran, F.A.; Heil, J.; Sohn, C.; Pantel, K.; et al. The impact of HER2 phenotype of circulating tumor cells in metastatic breast cancer: A retrospective study in 107 patients. BMC Cancer 2015, 15, 403. [CrossRef] 
126. Georgoulias, V.; Bozionelou, V.; Agelaki, S.; Perraki, M.; Apostolaki, S.; Kallergi, G.; Kalbakis, K.; Xyrafas, A.; Mavroudis, D. Trastuzumab decreases the incidence of clinical relapses in patients with early breast cancer presenting chemotherapy-resistant CK-19mRNA-positive circulating tumor cells: Results of a randomized phase II study. Ann. Oncol. 2012, 23, 1744-1750. [CrossRef]

127. Schramm, A.; Friedl, T.W.P.; Schochter, F.; Scholz, C.; de Gregorio, N.; Huober, J.; Rack, B.; Trapp, E.; Alunni-Fabbroni, M.; Müller, V.; et al. Therapeutic intervention based on circulating tumor cell phenotype in metastatic breast cancer: Concept of the DETECT study program. Arch. Gynecol. Obstet. 2016, 293, 271-281. [CrossRef]

128. Wong, K.H.K.; Tessier, S.N.; Miyamoto, D.T.; Miller, K.L.; Bookstaver, L.D.; Carey, T.R.; Stannard, C.J.; Thapar, V.; Tai, E.C.; Vo, K.D.; et al. Whole blood stabilization for the microfluidic isolation and molecular characterization of circulating tumor cells. Nat. Commun. 2017, 8, 1733. [CrossRef]

129. Lake, B.B.; Codeluppi, S.; Yung, Y.C.; Gao, D.; Chun, J.; Kharchenko, P.V.; Linnarsson, S.; Zhang, K. A comparative strategy for single-nucleus and single-cell transcriptomes confirms accuracy in predicted cell-type expression from nuclear RNA. Sci. Rep. 2017, 7, 6031. [CrossRef]

130. Macosko, E.Z.; Basu, A.; Satija, R.; Nemesh, J.; Shekhar, K.; Goldman, M.; Tirosh, I.; Bialas, A.R.; Kamitaki, N.; Martersteck, E.M.; et al. Highly Parallel Genome-wide Expression Profiling of Individual Cells Using Nanoliter Droplets. Cell 2015, 161, 1202-1214. [CrossRef]

131. Gierahn, T.M.; Wadsworth, M.H., 2nd; Hughes, T.K.; Bryson, B.D.; Butler, A.; Satija, R.; Fortune, S.; Love, J.C.; Shalek, A.K. Seq-Well: Portable, low-cost RNA sequencing of single cells at high throughput. Nat. Methods 2017, 14, 395-398. [CrossRef] [PubMed]

132. Klein, A.M.; Mazutis, L.; Akartuna, I.; Tallapragada, N.; Veres, A.; Li, V.; Peshkin, L.; Weitz, D.A.; Kirschner, M.W. Droplet barcoding for single-cell transcriptomics applied to embryonic stem cells. Cell 2015, 161, 1187-1201. [CrossRef] [PubMed]

133. Fan, H.C.; Fu, G.K.; Fodor, S.P. Expression profiling. Combinatorial labeling of single cells for gene expression cytometry. Science 2015, 347, 1258367. [CrossRef]

134. Cheng, Y.H.; Chen, Y.C.; Lin, E.; Brien, R.; Jung, S.; Chen, Y.T.; Lee, W.; Hao, Z.; Sahoo, S.; Min Kang, H.; et al. Hydro-Seq enables contamination-free high-throughput single-cell RNA-sequencing for circulating tumor cells. Nat. Commun. 2019, 10, 2163. [CrossRef] [PubMed]

135. Stott, S.L.; Hsu, C.H.; Tsukrov, D.I.; Yu, M.; Miyamoto, D.T.; Waltman, B.A.; Rothenberg, S.M.; Shah, A.M.; Smas, M.E.; Korir, G.K.; et al. Isolation of circulating tumor cells using a microvortex-generating herringbone-chip. Proc. Natl. Acad. Sci. USA 2010, 107, 18392-18397. [CrossRef]

136. Pantel, K.; Alix-Panabières, C. Liquid biopsy and minimal residual disease-Latest advances and implications for cure. Nat. Rev. Clin. Oncol. 2019, 16, 409-424. [CrossRef] [PubMed]

137. Sinkala, E.; Sollier-Christen, E.; Renier, C.; Rosàs-Canyelles, E.; Che, J.; Heirich, K.; Duncombe, T.A.; Vlassakis, J.; Yamauchi, K.A.; Huang, H.; et al. Profiling protein expression in circulating tumour cells using microfluidic western blotting. Nat. Commun. 2017, 8, 14622. [CrossRef]

138. Abouleila, Y.; Onidani, K.; Ali, A.; Shoji, H.; Kawai, T.; Lim, C.T.; Kumar, V.; Okaya, S.; Kato, K.; Hiyama, E.; et al. Live single cell mass spectrometry reveals cancer-specific metabolic profiles of circulating tumor cells. Cancer Sci. 2019, 110, 697-706. [CrossRef]

139. Deng, Y.; Zhang, Y.; Sun, S.; Wang, Z.; Wang, M.; Yu, B.; Czajkowsky, D.M.; Liu, B.; Li, Y.; Wei, W.; et al. An Integrated Microfluidic Chip System for Single-Cell Secretion Profiling of Rare Circulating Tumor Cells. Sci. Rep. 2014, 4, 7499. [CrossRef]

140. Lim, S.B.; Tan, S.J.; Lim, W.-T.; Lim, C.T. Compendiums of cancer transcriptomes for machine learning applications. Sci. Data 2019, 6, 194. [CrossRef]

141. Lim, S.B.; Tan, S.J.; Lim, W.-T.; Lim, C.T. A merged lung cancer transcriptome dataset for clinical predictive modeling. Sci. Data 2018, 5, 180136. [CrossRef] [PubMed]

(C) 2019 by the authors. Licensee MDPI, Basel, Switzerland. This article is an open access article distributed under the terms and conditions of the Creative Commons Attribution (CC BY) license (http://creativecommons.org/licenses/by/4.0/). 